North American Condyloderes (Kinorhyncha

Cyclorhagida: Kentrorhagata): Female dimorphism suggests moulting among adult Condyloderes

Sørensen, Martin V.; Thistle, David; Landers, Stephen C.

Published in:

Zoologischer Anzeiger

DOI:

10.1016/j.jcz.2019.05.015

Publication date:

2019

Document version

Publisher's PDF, also known as Version of record

Document license:

CC BY

Citation for published version (APA):

Sørensen, M. V., Thistle, D., \& Landers, S. C. (2019). North American Condyloderes (Kinorhyncha:

Cyclorhagida: Kentrorhagata): Female dimorphism suggests moulting among adult Condyloderes. Zoologischer Anzeiger, 282, 232-251. https://doi.org/10.1016/j.jcz.2019.05.015 
Research paper

\title{
North American Condyloderes (Kinorhyncha: Cyclorhagida: Kentrorhagata): Female dimorphism suggests moulting among adult Condyloderes ${ }^{\text {is }}$
}

\author{
Martin V. Sørensen ${ }^{\mathrm{a},}{ }^{*}$, David Thistle ${ }^{\mathrm{b}}$, Stephen C. Landers ${ }^{\mathrm{c}}$ \\ ${ }^{a}$ Natural History Museum of Denmark, University of Copenhagen, Øster Voldgade 5-7, DK-1350, Copenhagen, Denmark \\ b Department of Earth, Ocean and Atmospheric Sciences, Florida State University, Tallahassee, FL, 32306-4520, USA

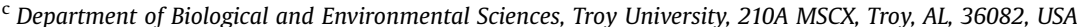

\section{A R T I C L E I N F O}

\section{Article history:}

Received 15 February 2019

Received in revised form

16 April 2019

Accepted 23 May 2019

Available online 6 June 2019

\section{Keywords:}

Deep-sea

Kinorhynchs

Meiofauna

Morphology

Taxonomy

\begin{abstract}
A B S T R A C T
Two new species of Condyloderes are described, C. rohalorum sp. nov. from the deep-sea off California, and Condyloderes flosfimbriatus sp. nov. from the continental shelf in the northern Gulf of Mexico. Additional species are furthermore reported from the two regions, including Condyloderes kurilensis from the Californian deep-sea, one potentially new species from each of the two regions, and the presence of specimens similar to, and potentially conspecific with, the two new species, i.e., Condyloderes cf. C. rohalorum sp. nov. in the Gulf of Mexico, and Condyloderes cf. C. flosfimbriatus sp. nov. from the Californian deep-sea. Examinations of $C$. rohalorum sp. nov. reveal that the species has two different adult female stages, hence representing the first example of adult female dimorphism known from this genus, and indicating that adult moulting might happen amongst species of Condyloderes.
\end{abstract}

(c) 2019 Elsevier GmbH. All rights reserved.

\section{Introduction}

Condyloderes used to be one of smaller and more species-poor kinorhynch genera. Literature on the genus has also been rather limited compared to other kinorhynch groups, but recently it has been subject of increased attention. I.e., Neuhaus et al. (2019) published a recent revision of the genus, and additional new species from the Mediterranean Sea are currently being described (Dal Zotto et al. 2019).

The first species of the genus was described from the Northeast Atlantic by McIntyre (1962) and named Centroderes multispinosus McIntyre, 1962. Less than ten years later, Higgins (1969) described the genus and its second species, Condyloderes paradoxus Higgins, 1969 from India, and reassigned McIntyre's Atlantic species to the genus (Higgins 1969). Subsequently, more than three decades followed before additional species appeared in the literature. Adrianov et al. (2002) described the Japanese species Condyloderes

This article is registered at www.zoobank.org under urn: lsid: zoobank.org:pub: 4B4BD70E-FA5B-499E-954B-10C19B17DA8D.

This article is a part of the Fifth International Scalidophora Workshop special issue published in Zoologischer Anzeiger 282C, 2019.

* Corresponding author.

E-mail address: mvsorensen@snm.ku.dk (M.V. Sørensen). setoensis Adrianov et al., 2002, and only two years later Condyloderes storchi Higgins, 2004 in Martorelli \& Higgins (2004) was described from the gut contents of a shrimp, off the coast of Argentina. A fifth species, Condyloderes megastigma Sørensen et al., 2010 was described from Korea (Sørensen et al. 2010), but this species was made a junior synonym of $C$. setoensis in the recent revision by Neuhaus et al. (2019). So far, all described Condyloderes had belonged to the continental fauna, but Adrianov \& Maiorova (2016) described the first deep-sea species of the genus, Condyloderes kurilensis Adrianov \& Maiorova, 2016, from 5.222 m depth on the abyssal plains near the drop of the Kuril-Kamchatka Trench. The most recent species, Condyloderes shirleyi Neuhaus \& Higgins, 2019 in Neuhaus et al., 2019, was described from Arctic waters around Alaska, and was part of the genus revision provided by Neuhaus et al. (2019). Hence, the genus currently accommodates six species, but with the addition of several new species described in the present volume (this contribution and Dal Zotto et al. 2019), the known diversity of the genus is nearly about to be doubled.

Species of Condyloderes are recognized by the presence of sixteen placids with peculiar knobby surfaces, combined with a trunk that appears conspicuously triangular in cross-section (Higgins 1969; Adrianov et al. 2002; Sørensen et al. 2010; Adrianov \& Maiorova 2016; Neuhaus et al. 2019). The first segment 
consists of a closed ring, segments 2 to 10 of one tergal and two sternal plates, and the terminal trunk segment of single tergal and sternal plates (Neuhaus et al. 2019). Acicular spines are found on all segments (except on segment 10 in females of certain species), and cuspidate spines are common as well. The latter often attach in lateral accessory to ventrolateral positions, as found in other kentrorhagids, but in certain species they are also present in the middorsal series (see, e.g., Martorelli \& Higgins 2004; Dal Zotto et al. 2019; Neuhaus et al. 2019), which is unique for this genus. The different characteristics make it easy to recognize the genus, but its only unique autapomorphy shared by all species is actually the placids with their conspicuous ornamentation.

\section{Materials and methods}

\subsection{Sampling and sample processing}

Samples off the US west coast were collected in September 2008 , during a deep-sea meiofauna cruise organized by second author, DT. More details on the cruise, and analyses of the general meiofauna abundance, are provided by Rohal et al. (2014). This cruise also yielded the loriciferans described by Neves et al. (2019) and several new and known kinorhynch species of the family Echinoderidae, reported by Sørensen et al. (2018). Details on stations relevant for the present study are listed in Table 1, and their locations are plotted in Fig. 1. For the sake of consistency, the present study uses the same station numbering as Neves et al. (2019) and Sørensen et al. (2018). Samples were collected from eight stations along the continental rise off southern Oregon and California, but only stations Cal- 4 to Cal-7, off California, had specimens of Condyloderes. Samples were taken with a multicorer on depths ranging from 2.719 to $3.853 \mathrm{~m}$. The top $1 \mathrm{~cm}$ from cores dedicated to meiofaunal studies were transferred directly to $95 \%$ alcohol and stored at $-20^{\circ} \mathrm{C}$ until further processing. In the laboratory the animals were stained with Rose Bengal, sorted to main groups, and transferred to glycerine for long term storage.

Specimens from the Gulf of Mexico were collected during a long-term sampling campaign under a GoMRI funded project managed by the last author SCL. This project already resulted in several kinorhynch contributions, focusing on the families Echinoderidae (Sørensen \& Landers 2014; Sørensen et al. 2016; Landers \& Sørensen 2016, 2018), Semnoderidae and Antygomonidae (Sørensen \& Landers 2018), Neocentrophyidae (Sørensen \& Landers 2017), and Pycnophyidae (Sánchez et al. 2019a), as well as general kinorhynch abundance in the Gulf of Mexico (Landers et al. 2018, 2019). Details on relevant stations are listed in Table 1, and positions are shown in Fig. 1. Station numbering follows the same numbering as in the Gulf of Mexico contributions cited above. Stations yielding specimens of Condyloderes were concentrated in two areas on the northern shelf of the Gulf: one western area south of Louisiana at depth range $88-113 \mathrm{~m}$, and a more eastern area, south of the Florida Panhandle at depth range 98-187 m (Table 1, Fig. 1). The sample from GoM 75-2012 was taken with a box corer, whereas all samples from the following years were taken with a multicorer. The sediment from the cores was fixed in $2-5 \%$ formaldehyde, and meiofauna was subsequently extracted by Ludox centrifugation (Burgess 2001) and transferred to 70\% isopropanol.

\subsection{Preparation and mounting of specimens}

Specimens for light microscopy (LM) were (if not already stored in glycerine) dehydrated through a graded series of alcohol/glycerine. When fully glycerinated, the specimens were mounted in Fluoromount G, either between a glass slide and a cover slip, or between two cover slips attached to a plastic H-S slide. The specimens were observed and documented with an Olympus BX51 light

Table 1

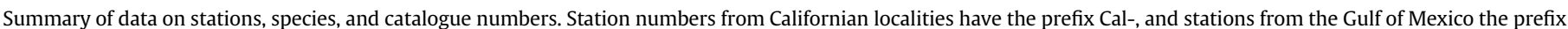
GoM. $\$ 1$ and $\$ 2$ indicate adult female stages 1 and 2, respectively.

\begin{tabular}{|c|c|c|c|c|c|c|}
\hline Station & Date & Position & Depth & Species & Mounting & Type status and catalogue numbers \\
\hline Cal-4 & Sep. 21-22, 2008 & $\begin{array}{l}39^{\circ} 59^{\prime} 53^{\prime \prime} \mathrm{N} \\
125^{\circ} 26^{\prime} 36^{\prime \prime} \mathrm{W}\end{array}$ & $2733 \mathrm{~m}$ & $\begin{array}{l}\text { Condyloderes sp. } 2 \\
\text { Condyloderes cf. } \\
\text { C. flosfimbriatus sp. nov. } \\
\text { C. kurilensis } \\
\text { C. rohalorum sp. nov. }\end{array}$ & $\begin{array}{l}\text { LM } \\
\text { LM } \\
\text { LM } \\
\text { LM }\end{array}$ & $\begin{array}{l}\text { 10 non-type, NHMD-289336 } \\
1 \sigma^{\star} \text { non-type, NHMD-288257 } \\
1 \sigma^{\star} \text { non-type, NHMD-289331 } \\
\text { o Holotype, NHMD-284986; } 1 \delta^{\star} \text { and } \\
1 \text { juvenile paratype, NHMD-284987-284988 }\end{array}$ \\
\hline Cal-5 & Sep. 23-25, 2008 & $\begin{array}{l}36^{\circ} 47^{\prime} 46^{\prime \prime} \mathrm{N} \\
123^{\circ} 41^{\prime} 54^{\prime \prime} \mathrm{W}\end{array}$ & $3679 \mathrm{~m}$ & C. kurilensis & LM & $1 \delta^{*}$ and 292 non-types, NHMD-289332-289334 \\
\hline Cal-6 & Sep. 24-25, 2008 & $\begin{array}{l}36^{\circ} 40^{\prime} 52^{\prime \prime} \mathrm{N} \\
122^{\circ} 49^{\prime} 37^{\prime \prime} \mathrm{W}\end{array}$ & $2719 \mathrm{~m}$ & $\begin{array}{l}\text { Condyloderes sp. } 2 \\
\text { Condyloderes } \mathrm{cf} . \\
\text { C. flosfimbriatus sp. nov. } \\
\text { C. kurilensis } \\
\text { C. rohalorum sp. nov. }\end{array}$ & $\begin{array}{l}\text { SEM } \\
\text { SEM } \\
\text { LM } \\
\text { SEM }\end{array}$ & $\begin{array}{l}1 \% 2 \text { non-type } \\
1 \text { क non-type } \\
1 \text { } 2 \text { non-type, NHMD- } 289335 \\
1 \$ 1,2 \text { } 2 \text { and } 1 \text { juvenile non-types }\end{array}$ \\
\hline Cal-7 & Sep. 27-29, 2008 & $\begin{array}{l}32^{\circ} 52^{\prime} 40^{\prime \prime} \mathrm{N} \\
120^{\circ} 36^{\prime} 31^{\prime \prime} \mathrm{W}\end{array}$ & $3853 \mathrm{~m}$ & C. kurilensis & SEM & $20^{\star}$ and 192 non-types \\
\hline GoM 75-2012 & Oct. 23, 2012 & $\begin{array}{l}28^{\circ} 07^{\prime} 28^{\prime \prime} \mathrm{N} \\
090^{\circ} 53^{\prime} 37^{\prime \prime} \mathrm{W}\end{array}$ & $113 \mathrm{~m}$ & C. flosfimbriatus sp. nov. & LM & 1 Juvenile non-type, NHMD-286562 \\
\hline GoM 74-2013 & Nov. 14, 2013 & $\begin{array}{l}29^{\circ} 49^{\prime} 13^{\prime \prime} \mathrm{N} \\
086^{\circ} 59^{\prime} 06^{\prime \prime} \mathrm{W}\end{array}$ & $186 \mathrm{~m}$ & Condyloderes sp. 1 & LM & 10` non-type, NHMD-286563 \\
\hline GoM 79-2013 & Nov. 15, 2013 & $\begin{array}{l}29^{\circ} 48^{\prime} 21^{\prime \prime} \mathrm{N} \\
086^{\circ} 36^{\prime} 03^{\prime \prime} \mathrm{W}\end{array}$ & $125 \mathrm{~m}$ & $\begin{array}{l}\text { Condyloderes cf. } \\
\text { C. rohalorum sp. nov. }\end{array}$ & SEM & 1 2 non-type \\
\hline GoM 04-2014 & Nov. 02, 2014 & $\begin{array}{l}28^{\circ} 08^{\prime} 34^{\prime \prime} \mathrm{N} \\
090^{\circ} 57^{\prime} 05^{\prime \prime} \mathrm{W}\end{array}$ & $97 \mathrm{~m}$ & $\begin{array}{l}\text { Condyloderes cf. } \\
\text { C. rohalorum sp. nov. }\end{array}$ & LM & 1 Juvenile non-type, NHMD-289262 \\
\hline GoM 25-2014 & Nov. 16, 2014 & $\begin{array}{l}28^{\circ} 07^{\prime} 07^{\prime \prime} \mathrm{N} \\
091^{\circ} 49^{\prime} 34^{\prime \prime} \mathrm{W}\end{array}$ & $88 \mathrm{~m}$ & C. flosfimbriatus sp. nov. & SEM & $1 \delta^{\top}$ non-type \\
\hline GoM 29-2014 & Nov. 19, 2014 & $\begin{array}{l}29^{\circ} 58^{\prime} 29^{\prime \prime} \mathrm{N} \\
086^{\circ} 48^{\prime} 02^{\prime \prime} \mathrm{W}\end{array}$ & $125 \mathrm{~m}$ & C. flosfimbriatus sp. nov. & LM & 10 paratype, NHMD-288247 \\
\hline GoM 31-2014 & Nov. 20, 2014 & $\begin{array}{l}29^{\circ} 39^{\prime} 35^{\prime \prime} \mathrm{N} \\
086^{\circ} 34^{\prime} 58^{\prime \prime} \mathrm{W}\end{array}$ & $163 \mathrm{~m}$ & $\begin{array}{l}\text { C. flosfimbriatus sp. nov. } \\
\text { Condyloderes cf. } \\
\text { C. rohalorum sp. nov. }\end{array}$ & $\begin{array}{l}\text { LM } \\
\text { LM }\end{array}$ & $\begin{array}{l}\text { } 1 \text { holotype, NHMD-286561 } \\
1 \delta^{\star} \text { non-type, NHMD-285790 }\end{array}$ \\
\hline GoM 33-2014 & Nov. 20, 2014 & $\begin{array}{l}29^{\circ} 32^{\prime} 32^{\prime \prime} \mathrm{N} \\
086^{\circ} 11^{\prime} 33^{\prime \prime} \mathrm{W}\end{array}$ & $98 \mathrm{~m}$ & C. flosfimbriatus sp. nov. & SEM & $10^{\pi}$ non-type \\
\hline
\end{tabular}


microscope with differential interference contrast and an Olympus DP27 camera. All specimens mounted for LM are deposited in the collection of the Natural History Museum of Denmark (NHMD) (see Table 1 for catalogue numbers).

Glycerine-stored Californian specimens for scanning electron microscopy (SEM) were rinsed following the procedure described by Sørensen et al. (2018). After rinsing, the specimens were dehydrated again through a graded ethanol series to $99,9 \%$ ethanol. Specimens from the Gulf of Mexico, already stored in 70\% isopropanol, were transferred directly to ethanol. All specimens were subsequently critical point dried, mounted on sticky carbon tabs on SEM aluminium stubs, sputter coated with either gold or a platinum/ palladium mix, and examined with a JEOL JSM-6335F Field Emission SEM (NHMD) or a Zeiss EVO 50 SEM (Auburn University Research Instrumentation Facility, Auburn, AL, USA). Specimens mounted for SEM are stored in the personal reference collections of the authors.

\subsection{Description and documentation}

Line art illustrations were based on light microscopical images imported into Adobe Illustrator CS6, and with information from SEM added. All photos were edited with Adobe Photoshop CS6, and figure plates were prepared with Illustrator. The morphological terminology follows Neuhaus et al. (2019), whereas the terminology used for positions of cuticular structures along the trunk segments follows Sørensen et al. (2010), and hence, differs slightly from the one used by Neuhaus et al. (2019). The terminology from Sørensen et al. (2010) is used, because it is more suitable for specimens with trunks being triangular in cross-section. The commonly used terminology for cyclorhagid kinorhynchs is developed for specimens with a rounder or heart-shaped cross-section, e.g., as typically found in species of Echinoderidae, and the definitions of some positions do not apply to a triangular cross-section.

\section{Results}

\section{Taxonomic account}

Class Cyclorhagida (Zelinka 1896) Sørensen et al. 2015

Order Kentrorhagata Sørensen et al. 2015

Family Centroderidae Zelinka 1896

Genus Condyloderes Higgins, 1969

\subsection{Condyloderes rohalorum $s p$. nov.}

(Figs 1-3 and Tables 2,3) 3B1FB

\subsubsection{Diagnosis}

Condyloderes with middorsal and lateroventral acicular spines on segments 1 to 9 , and cuspidate spines in lateral accessory positions on segments 1 and 8 , and in ventrolateral positions on segment 5 . Adult males and stage 1 females with acicular spines in middorsal and laterodorsal positions on segment 10 ; stage 2 females have no spines on segment 10. All adult females with protuberant appendages in ventromedial positions on segments 7 and 8; densely papillated sensorial areas on segment 9 never present in females.

\subsubsection{Etymology}

This species is dedicated to Dr Melissa Rohal, in recognition of her work on meiofauna in the Gulf of Mexico and the Californian deep-sea, and to her family on paternal side for always supporting her through work and life.

\subsubsection{Examined material}

Holotype, adult male, collected from mud on September 21, 2008, at St. Cal-4 at 2.733 m depth off northern California, US West Coast $\left(39^{\circ} 59^{\prime} 53^{\prime \prime} \mathrm{N}, 125^{\circ} 26^{\prime} 36^{\prime \prime} \mathrm{W}\right)$, mounted in Fluoromount G, and deposited at NHMD under catalogue number NHMD-284986. Paratypes include one adult male and one juvenile specimen, collected at same locality as the holotype, mounted in Fluoromount G, and deposited at NHMD under catalogue numbers NHMD-284987 and 284988. Additional non-type specimens from California used in the description include one female stage 1 , two females stage 2 , and one juvenile, all from St. Cal-6, mounted for SEM and stored in the first author's personal reference collection. Other non-types include three specimens from the Gulf of Mexico that were examined, but did not contribute to the description. Due to the different locality and minor differences addressed below, the specimens are treated as Condyloderes $\mathrm{cf}$. C. rohalorum. The specimens include one adult male, collected at St. GoM 31-2014, and one juvenile, collected at St. GoM 04-2014, both mounted in Fluoromount $\mathrm{G}$, and deposited at NHMD, under catalogue numbers NHMD-285790 and NHMD-289262, and one stage 2 female from St. GoM 79-2013, mounted for SEM and stored in the last author's personal reference collection. See Fig. 1 for localities and Table 1 for detailed station data.

\subsubsection{Description}

Adults with head, neck and eleven trunk segments (Figs. 2A, B, $3 \mathrm{~A}, \mathrm{~B}, 4 \mathrm{~A})$. For complete overview of measurements and dimensions, see Table 2. Distribution of cuticular structures, i.e., sensory spots and spines, is summarized in Table 3.

The head consists of a retractable mouth cone and an introvert (Fig. 4B, C). The external mouth cone armature consists of nine

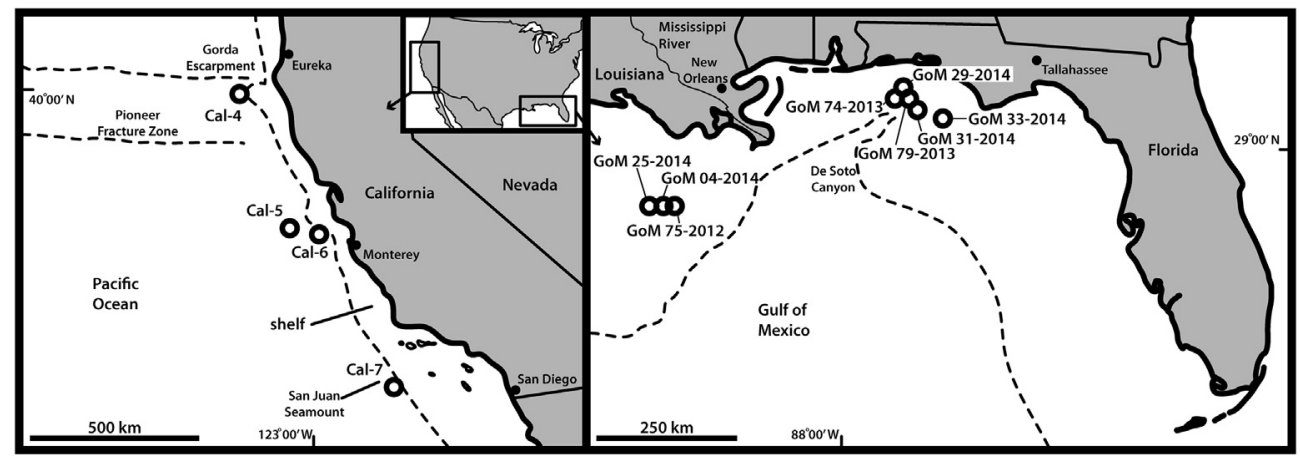

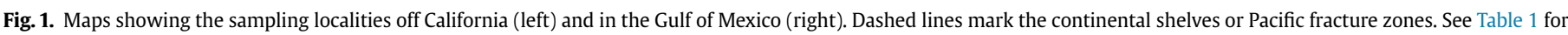
further details on the localities. 
A
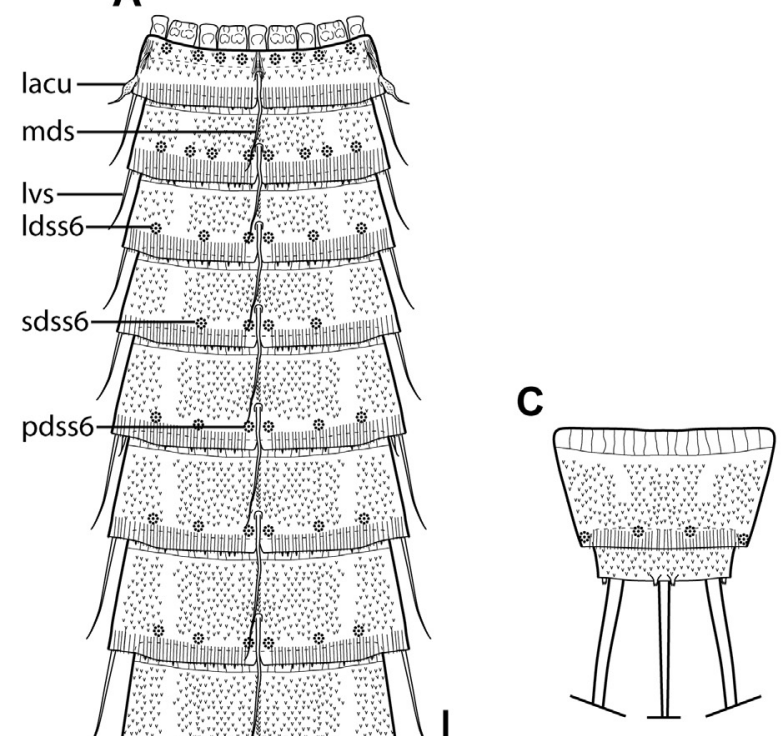

B

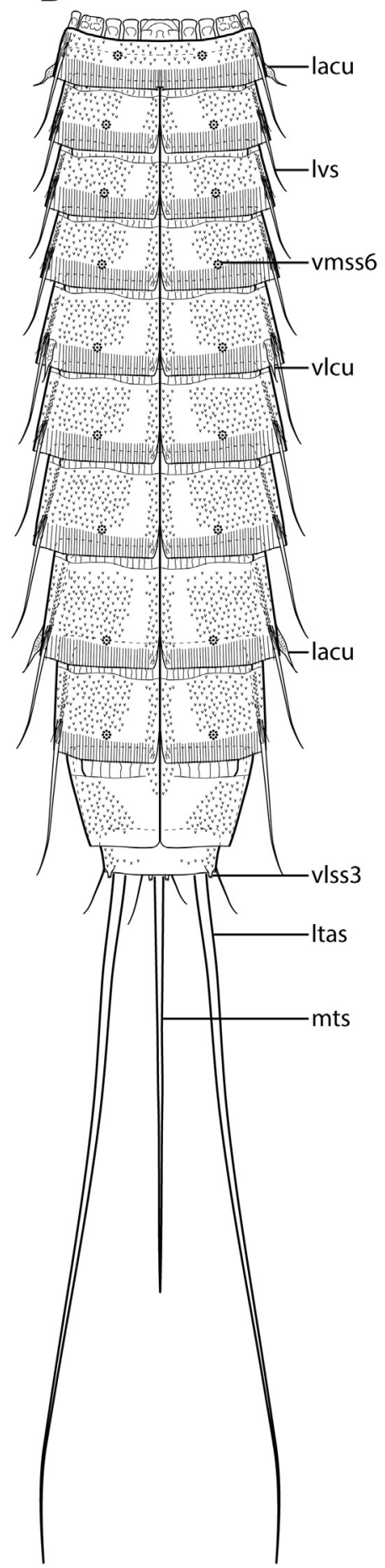

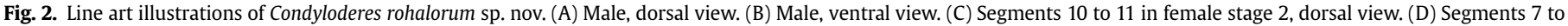

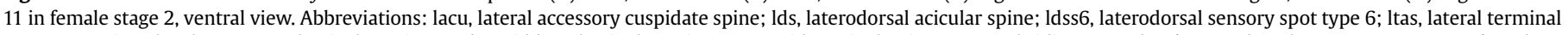

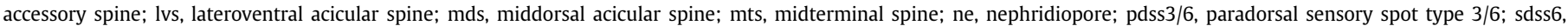

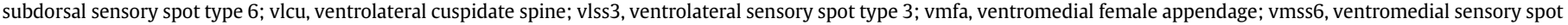
type 6 .

articulated outer oral styles, each composed of a thick proximal unit, and a much thinner and more flexible distal unit (Fig. 4B). Outer oral styles are located anterior to each introvert sector, except the middorsal sector 6 . Dense fringes with fringes tips in two or three layers are located basal to each stylet.
One specimen had its introvert nearly fully everted (Fig. 4C), but it was still impossible to obtain information on scalid arrangements in some sectors and the most posterior rings. The scalid arrangement appeared to be very similar, if not identical, to $C$. shirleyi (see Neuhaus et al. 2019). Besides the regular spinoscalids, fourteen 

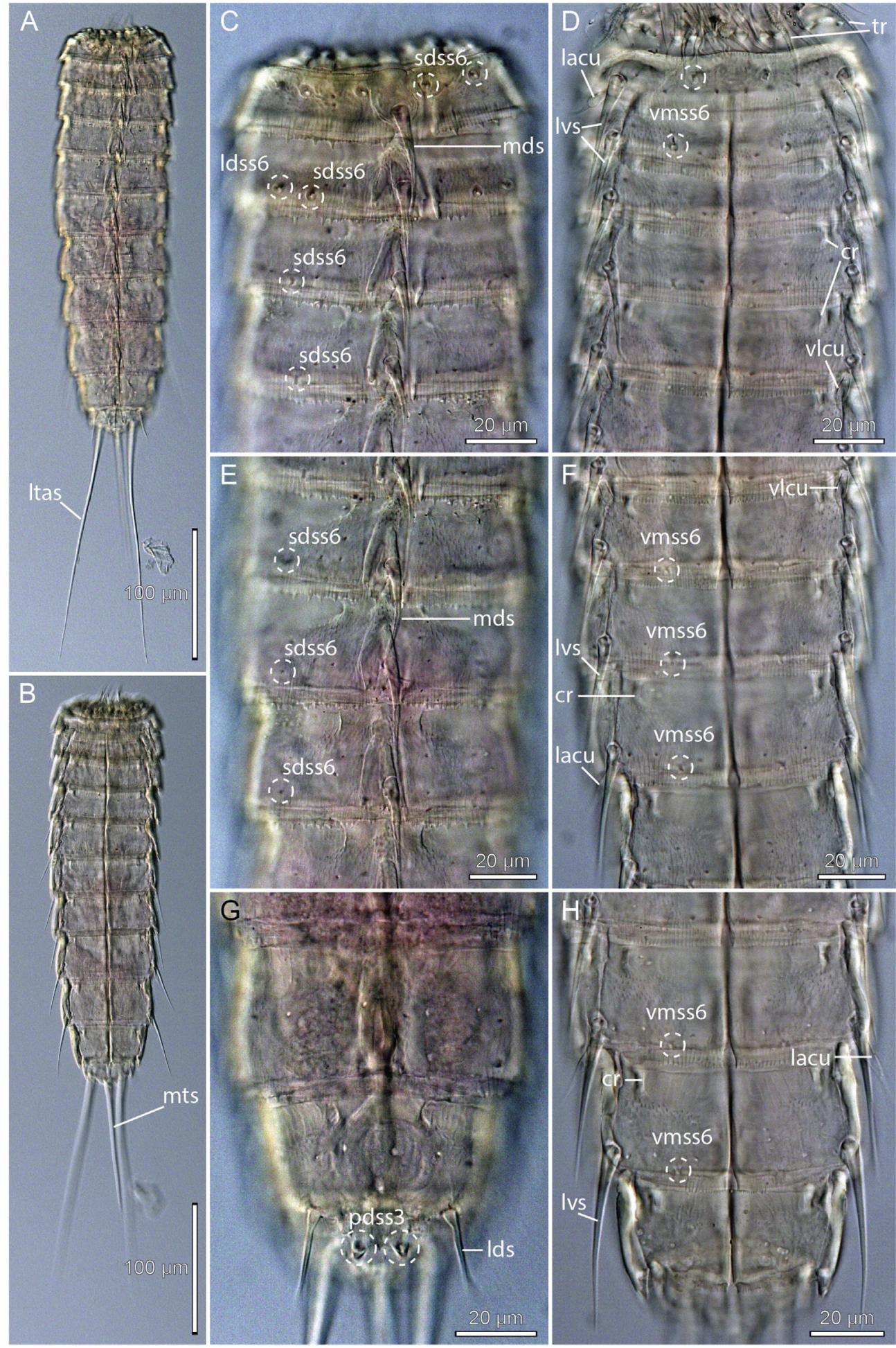

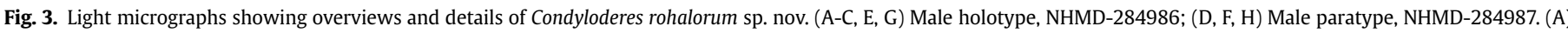

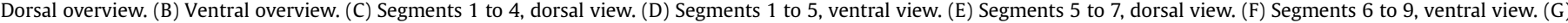

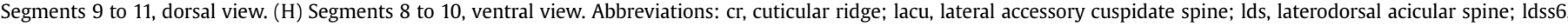

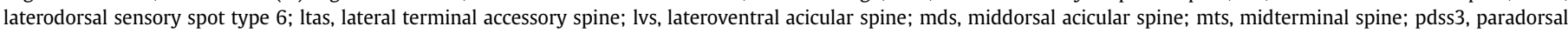
sensory spot type 3; sdss6, subdorsal sensory spot type 6; tr, trichoscalid; vlcu, ventrolateral cuspidate spine; vmss6, ventromedial sensory spot type 6.

trichoscalids are present, each flanked by a pair of filamentous appendages.

The neck has sixteen placids with condyles: the midventral placid is broadest, measuring $13 \mu \mathrm{m}$ in width at its base; other placids are either broad ( $11 \mu \mathrm{m}$ wide), or narrow ( $8 \mu \mathrm{m}$ wide); broad and narrow placids alternate, except in ventromedial positions, where two narrow placids are located next to each other (Fig. 2A, B). The midventral placid has three knobby projections posteriorly on its exterior surface, and two more anterior ones that project from the placid; other broad placids have two posterior and 
Table 2

Measurements from light microscopy for two types and one non-type of questionable identity of Condyloderes rohalorum sp. nov. (in $\mu \mathrm{m})$. Abbreviations: (ac): acicular spine; (cu): cuspidate spine; LA: lateral accessory; LD: laterodorsal; LTAS: lateral terminal accessory spine; LV: lateroventral; MD, middorsal; MSW-7: maximum sternal width, measured on segment 7 in this species; MTS: midterminal spine; S: segment lengths; SW-10, standard width, always measured on segment 10; TL: trunk length; VL: ventrolateral; - damaged structure impossible to measure.

\begin{tabular}{|c|c|c|c|}
\hline \multirow[t]{3}{*}{ Character } & \multirow{3}{*}{$\frac{\frac{\delta \text { Holotype }}{\text { NHMD-284986 }}}{\text { Cal-4 }}$} & \multirow{3}{*}{$\frac{\frac{\text { o Paratype }}{\text { NHMD-284987 }}}{\text { Cal-4 }}$} & \multirow{3}{*}{$\frac{\frac{\text { o Non-type }}{\text { NHMD-285790 }}}{\text { GoM 31-2014 }}$} \\
\hline & & & \\
\hline & & & \\
\hline $\mathrm{TL}$ & 321 & 267 & 247 \\
\hline MSW-7 & 72 & 70 & 59 \\
\hline MSW-7/TL & $22.4 \%$ & $26.2 \%$ & $23.9 \%$ \\
\hline SW-10 & 60 & 53 & 44 \\
\hline SW-10/TL & $18.7 \%$ & $19.9 \%$ & $17.8 \%$ \\
\hline S1 & 25 & 21 & 21 \\
\hline S2 & 32 & 30 & 26 \\
\hline S3 & 32 & 30 & 29 \\
\hline S4 & 36 & 31 & 28 \\
\hline S5 & 39 & 33 & 32 \\
\hline S6 & 40 & 35 & 32 \\
\hline S7 & 42 & 39 & 31 \\
\hline S8 & 43 & 40 & 34 \\
\hline S9 & 45 & 40 & 34 \\
\hline S10 & 39 & 36 & 30 \\
\hline S11 & 25 & 26 & 17 \\
\hline MD1 (ac) & 32 & 36 & 26 \\
\hline MD2 (ac) & 31 & 35 & 28 \\
\hline MD3 (ac) & 33 & 35 & 27 \\
\hline MD4 (ac) & 36 & 38 & 32 \\
\hline MD5 (ac) & 35 & 37 & 33 \\
\hline MD6 (ac) & 43 & 36 & 38 \\
\hline MD7 (ac) & 46 & 42 & 39 \\
\hline MD8 (ac) & 53 & 48 & - \\
\hline MD9 (ac) & 54 & 51 & - \\
\hline MD10 (ac) & 31 & 37 & 31 \\
\hline LV1 (ac) & 38 & 35 & 33 \\
\hline LA1 (cu) & 13 & 14 & 12 \\
\hline LV2 (ac) & 36 & 31 & 28 \\
\hline LV3 (ac) & 36 & 34 & 28 \\
\hline LV4 (ac) & 40 & 33 & 28 \\
\hline LV5 (ac) & 42 & 37 & 32 \\
\hline VL5 (cu) & 18 & 17 & 15 \\
\hline LV6 (ac) & 47 & 35 & 34 \\
\hline LV7 (ac) & 46 & 42 & 36 \\
\hline LV8 (ac) & 47 & 48 & 35 \\
\hline LA8 (cu) & 26 & 19 & 16 \\
\hline LV9 (ac) & 61 & 54 & 45 \\
\hline LD10 (ac) & 29 & 30 & 29 \\
\hline MTS & 182 & 104 & 105 \\
\hline LTAS & 318 & 187 & 171 \\
\hline MTS/LTAS & $57.2 \%$ & $55.6 \%$ & $61.4 \%$ \\
\hline LTAS/TL & $99.1 \%$ & $70.0 \%$ & $69.2 \%$ \\
\hline
\end{tabular}

two more anterior projections on exterior surface and two apical projecting ones, whereas narrow placids have one posterior and one anterior projection on their exterior surface.

The trunk is nearly triangular in cross-section and nearly parallel-sided in ventral view, with segment 1 consisting of a closed ring, segments 2 to 10 consisting of one tergal and two sternal plates, and segment 11 consisting of one tergal and one sternal plate. The cuticular ornamentation of segments 2 to 11 is divided into three transverse zones: 1) an anterior zone with irregular, longitudinal lines or wrinkles, 2) a median zone densely covered with cuticular hairs, and 3) a posterior zone (representing the free flap) with more regularly arranged longitudinal lines (Fig. 4D-M). Segment 1 has only two zones, an anterior with hair and the free flap posteriorly (Fig. 4D, E). Ventromedial crescentic cuticular ridges are present in the anterior transverse zone on segments 2 to
10. Cuticular hairs are small, triangular scales covering the entire transverse zones, except for hairless patches in laterodorsal (segments 2 to 10) and ventromedial (segments 1 to 10) positions, representing muscle attachment sites (Fig. 2A, B). Posterior segment margins are finely serrated, where each tooth is a continuation of the longitudinal lines on the free flap (Fig. 4D, F, H, J, $\mathrm{K}-\mathrm{L}$ ). The margins are generally straight, except for larger, toothlike extensions that appear in different positions (differing independently between the specimens).

Segment 1 with middorsal and lateroventral acicular spines, and lateral accessory cuspidate spines (Figs. 2A, B, 3C, D, 4D, E). Acicular spines on this and all following segments consist of a short, smooth base, and an end-piece densely covered with minute hairs. Minute hairs are also present on cuspidate spines on this and all other segments. Tufts of long hairs emerge anterior to the acicular spines. Sensory spots type 6 present as two subdorsal pairs, two laterodorsal pairs and single ventromedial pair; sensory spots on tergal plate near anterior segment margin; those on sternal plate medially in hairy zone.

Segment 2 with middorsal and lateroventral acicular spines; base of lateroventral spines on this and all following segments flanked by a tuft of filamentous hairs (Figs. 2A, B, 3C, D, 4D, E). Sensory spots type 6 present as single pairs in paradorsal, subdorsal, and ventromedial positions, and as a double pair in laterodorsal positions, flanking the hairless muscle attachment sites; all sensory spots on this and following eight segments located in the intersection between the transverse hairy zone and the free flap.

Segment 3 with middorsal and lateroventral acicular spines (Figs. 2A, B, 3C, D, 4D, E). Sensory spots type 6 present in paradorsal, subdorsal, laterodorsal and ventromedial positions.

Segment 4 with middorsal and lateroventral acicular spines (Figs. 2A, B, 3C, D, 4F, G). Sensory spots type 6 present in paradorsal, subdorsal, and ventromedial positions.

Segment 5 with ventrolateral cuspidate spines (Figs. 2A, B, 3D, F, $4 \mathrm{~F}, \mathrm{G})$. Otherwise similar to segment 3.

Segment 6 similar to segment 3 (Figs. 2A, B, 3E, F, 4H).

Segment 7 similar to segment 6 in males (Figs. 2A, B, 3E, F, 4H). All females additionally with a pair of protuberant appendages in ventromedial positions, anterior to, and more lateral than sensory spots (Figs. 2D and 4J).

Segment 8 with middorsal and lateroventral acicular spines, and lateral accessory cuspidate spines (Figs. 2A, B, 3F, H, 4I, J). Sensory spots type 6 present in paradorsal, laterodorsal and ventromedial positions. All females additionally with a pair of protuberant appendages in ventromedial positions, anterior to, and more midventral than sensory spots (Figs. 2D and 4J).

Segment 9 with middorsal and lateroventral acicular spines (Figs. 2A, B, 3G, H, 4I, M). Sensory spots type 6 present in subdorsal, laterodorsal and ventromedial positions. Nephridiopore marked as tuft of minute papillae (Fig. 4I), present next to laterodorsal sensory spots (closer to subdorsal position). Densely papillated sensory areas on the sternal plates, as known from females in other species of Condyloderes, are not present (Figs. 2D and $4 \mathrm{M})$.

Segment 10 with sensory spots type 6 present in lateral accessory positions in all adult stages. Males with thin acicular spines in middorsal and laterodorsal positions (Figs. 2A, B, 3G, H). Adult females present as two different morphotypes, and are referred to as 'stage 1 females' and 'stage 2 females'. Stage 1 females with thin acicular spines in middorsal and laterodorsal positions (Fig. 4K). Stage 2 females without any spines on this segment, but with sensory spots type 6 in subdorsal positions (Figs. 2C and 4L).

Segment 11 with midterminal and lateral terminal accessory spines (Figs. 2A, B, 3A, B, 4A). Sensory spots type 3 present near and protruding beyond posterior segment margin in paradorsal 
Table 3

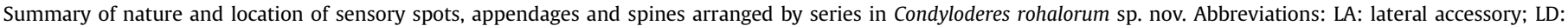

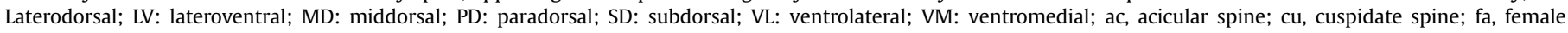

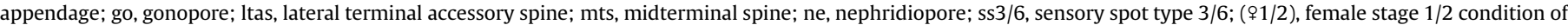
sexually dimorphic character; $\left({ }^{\star}\right)$, male condition of sexually dimorphic character.

\begin{tabular}{|c|c|c|c|c|c|c|c|c|}
\hline $\begin{array}{l}\text { Position } \\
\text { Segment }\end{array}$ & MD & PD & SD & LD & LA & LV & VL & VM \\
\hline 1 & ac & & ss6,ss6 & ss6,ss6 & $\mathrm{cu}$ & ac & & ss6 \\
\hline 2 & ac & ss6 & ss6 & ss6,ss6 & & ac & & ss6 \\
\hline 3 & ac & ss6 & ss6 & ss6 & & $\mathrm{ac}$ & & ss6 \\
\hline 4 & ac & ss6 & ss6 & & & ac & & ss6 \\
\hline 5 & ac & ss6 & ss6 & ss6 & & ac & $\mathrm{cu}$ & ss6 \\
\hline 6 & ac & ss6 & ss6 & ss6 & & ac & & ss6 \\
\hline 7 & ac & ss6 & ss6 & ss6 & & ac & & $\mathrm{fa}(+1+2), \mathrm{ss} 6$ \\
\hline 8 & ac & ss6 & & ss6 & $\mathrm{cu}$ & ac & & ss6, fa $(q 1+2)$ \\
\hline 9 & $\mathrm{ac}$ & & ss6 & ne,ss6 & & ac & & ss6 \\
\hline 10 & 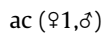 & & ss6 (2) & $\mathrm{ac}\left(\$ 1,0^{\star}\right)$ & ss6 & & & \\
\hline 11 & $\mathrm{mts}$ & ss3 & & & ltas & & go $(\$ 1+2), s s 3$ & \\
\hline
\end{tabular}

(Fig. 3G) and ventrolateral positions. Both female stages with gonopores in ventrolateral positions, anteriorly on the segment.

\subsubsection{Notes on Condyloderes $c f$. C. rohalorum from the Gulf of Mexico}

Two specimens showing great resemblance with $C$. rohalorum sp. nov. were collected in the Gulf of Mexico. One male specimen (St. GoM 31-2014) was mounted for LM, and the other, a stage 2 female (St. GoM 79-2013) for SEM. Measurements for the LM specimen are provided in Table 2 . This specimen is generally smaller than the two Californian type specimens, but not that much smaller than the paratype. The spine pattern in the two Gulf of Mexico specimens was nearly identical with the pattern in the type specimens. The only difference was the laterodorsal spines on segment 10 in the male, which appeared to be crenulated, opposite to the acicular spines in the type specimens. This could, however, just indicate that the Gulf specimen represented a different adult male stage of $C$. rohalorum sp. nov. Comparison of distribution of sensory spots between the Californian and Gulf of Mexico specimens revealed only minor differences. No differences at all were found in the male LM specimen, whereas the female SEM specimen appeared to lack subdorsal sensory spots on segments 6 and 7 . However, Neuhaus et al. (2019) showed that the exact distribution of sensory spots may vary within species of Condyloderes, hence the female SEM species could still be considered conspecific with C. rohalorum sp. nov. despite these two, minor differences in sensory spot distribution. The only problem that speaks against conspecifity between the Californian and the Gulf of Mexico specimens is the considerable distance and geographic separation of the populations. Hence, with this small hesitation we will for now step carefully and refer to the Gulf of Mexico species as Condyloderes cf. C. rohalorum sp. nov., but we would expect that eventual future morphological and/or molecular analyses would confirm that they are indeed conspecific with $C$. rohalorum sp. nov.

\subsubsection{Notes on diagnostic and taxonomic features in $\mathrm{C}$. rohalorum sp. nov.}

C. rohalorum sp. nov. is distinguished from other congeners by its distribution of cuspidate spines, and in particular the presence of cuspidate spines in the lateral series of segment 1 . C. storchi is the only other Condyloderes with cuspidate spines in the lateral series of segment 1 (Martorelli \& Higgins 2004). However, this species has also middorsal cuspidate spines on segments 5 and 7, and ventrolateral cuspidate spines on segment 9 (Martorelli \& Higgins 2004; Neuhaus et al. 2019), which easily distinguishes it from C. rohalorum sp. nov.
A second uncommon trait in C. rohalorum sp. nov. is the absence of cuspidate spines on segment 9 . Among the known and described congeners, only C. kurilensis lacks cuspidate spines on segment 9 (Adrianov \& Maiorova 2016; Neuhaus et al. 2019). C. kurilensis also lacks cuspidate spines on segment 1 though, which makes it easy to distinguish from $C$. rohalorum sp. nov.

\subsection{Condyloderes flosfimbriatus sp. nov.}

(Figs 4-7 and Tables 4,5)

urn:Isid:zoobank.org:act: 72E1A164-D29A-4F6A-898D-FCBCC 3F99FF0

\subsubsection{Diagnosis}

Condyloderes with middorsal and lateroventral acicular spines on segments 1 to 9 , cuspidate spines in ventrolateral positions on segments 2, 5 and 9, and in lateral accessory positions on segment 8. Adult males and stage 1 females with acicular spines in middorsal and laterodorsal positions on segment 10. Stage $1 \mathrm{fe}-$ males furthermore with protuberant appendages in ventromedial positions on segments 7 and 8 , and ventromedial areas of densely set micropapillae on segment 9; stage 2 females unknown or not existing. Posterior segment margin of tergal plates of segments 1 and 10, and tergal + sternal plates of segments 2 to 9 with fringes forming flower-like extensions.

\subsubsection{Etymology}

This species is named flosfimbriatus after the Latin flos- = flower and -fimbriatus $=$ fringe, with reference to the flower-like fringes along most of the posterior margins of segments 1 to 10 .

\subsubsection{Examined material}

Holotype, adult stage 1 female, collected from mud on November 20, 2014, on St. GoM 31-2014 at $163 \mathrm{~m}$ depth, south of the Florida Panhandle in the Gulf of Mexico $\left(29^{\circ} 39^{\prime} 35^{\prime \prime} \mathrm{N}\right.$ $086^{\circ} 34^{\prime} 58^{\prime \prime} \mathrm{W}$ ), mounted in Fluoromount G, and deposited at NHMD under catalogue number NHMD-286561. Paratypes include one male, collected from mud on November 19, 2014, on St. GoM 29-2014 at $125 \mathrm{~m}$ depth, also south of the Florida Panhandle $\left(29^{\circ} 58^{\prime} 29^{\prime \prime} \mathrm{N}, 086^{\circ} 48^{\prime} 02^{\prime \prime} \mathrm{W}\right)$, mounted in Fluoromount G, and deposited at NHMD under catalogue number NHMD-288247. Nontypes from the Gulf of Mexico include one juvenile specimen from St. GoM 75-2012, mounted in Fluoromount G, and deposited at NHMD under catalogue number NHMD-286562, and two males from St. GoM 25-2014 and GoM 33-2014, respectively, mounted for SEM and stored in the first author's personal reference collection. 

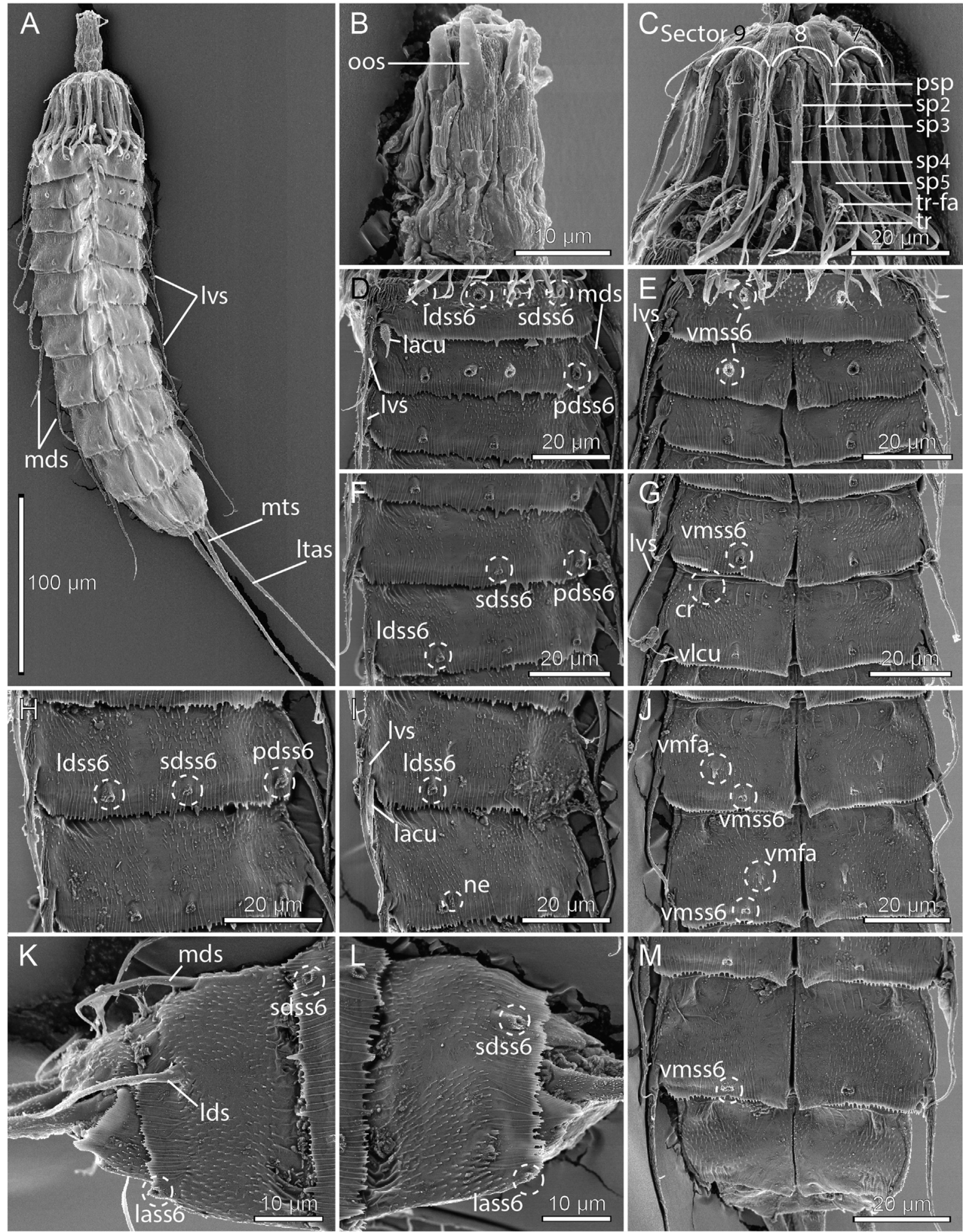

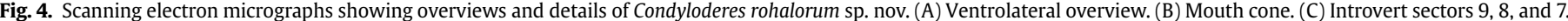

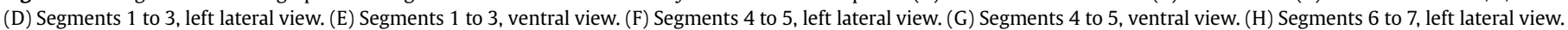

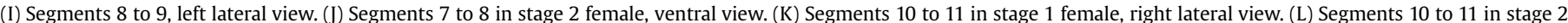

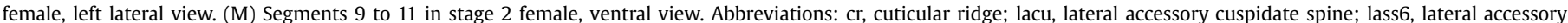

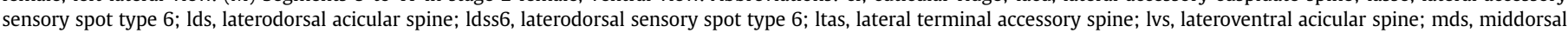

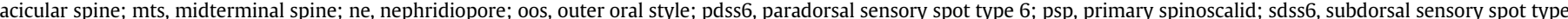

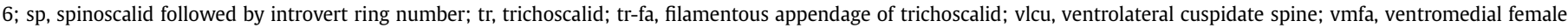
appendage; vmss6, ventromedial sensory spot type 6 . 
A

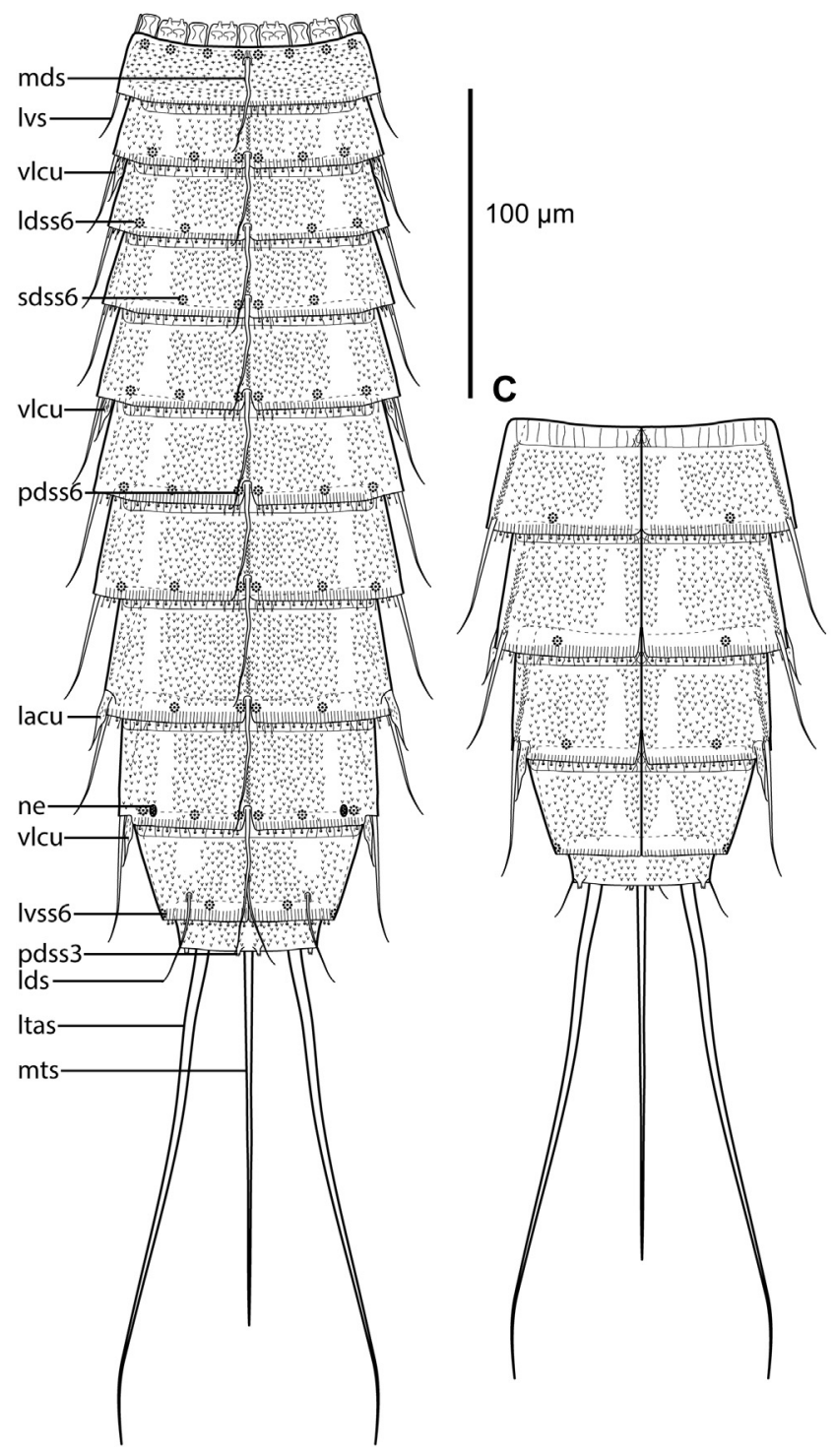

B

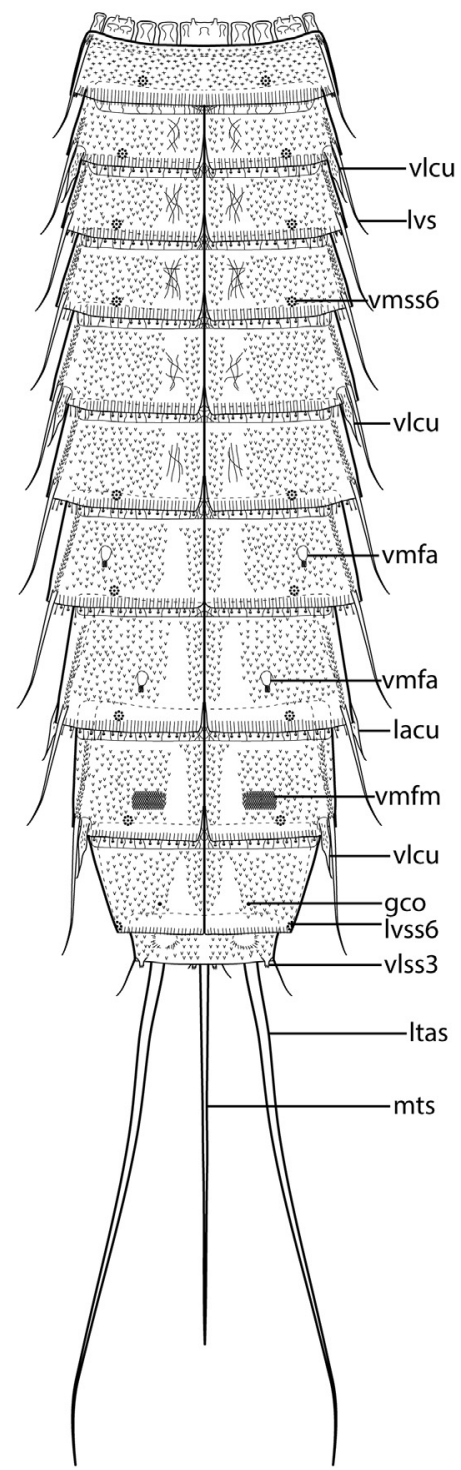

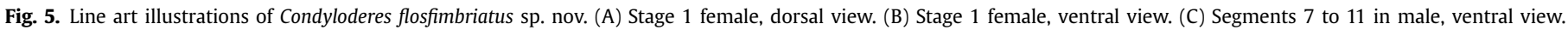

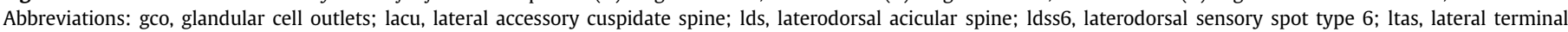

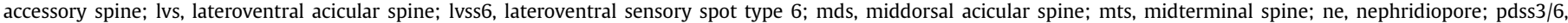

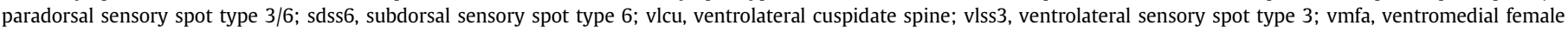
appendage; vmfm, ventromedial area of female micropapillae; vmss6, ventromedial sensory spot type 6 .

Two specimens showing great resemblance with the new species were found in the Californian deep-sea material. These include one male from St. Cal-4, mounted in Fluoromount G, and deposited at NHMD, under catalogue number NHMD-288257, and one male from St. Cal-6, mounted for SEM and stored in the first author's personal reference collection. The specimens only differed from the type specimens from the Gulf of Mexico at very few details (see specific comments in section 3.2.5), but due to these difference and the distance between the type locality and the Californian deep-sea, they are for now treated as Condyloderes cf. Condyloderes flosfimbriatus.

See Fig. 1 for localities and Table 1 for detailed station data.

\subsubsection{Description}

Adults with head, neck and eleven trunk segments (Figs. 5A, B, $6 \mathrm{~A}, \mathrm{~B}, 7 \mathrm{~A}, \mathrm{~B})$. For complete overview of measurements and dimensions, see Table 4. Distribution of cuticular structures, i.e., sensory spots and spines, is summarized in Table 5. The description includes information on male and female stage 1 morphology; eventual existence and thus morphology of stage 2 females is not known.

The head consists of a retractable mouth cone and an introvert. The external mouth cone armature consists of nine articulated outer oral styles (Fig. 7C). The styles are gradually tapering towards their tips, and each style is composed of two units, with a very fine, anteriorly directed fringe at the joint of the unit. Outer oral styles are located anterior to each introvert sector, except the middorsal sector 6. No conspicuous structures are present at the bases of the styles.

Only one SEM specimen had its introvert nearly fully everted (Fig. 7D), and it was only possible to observe scalid arrangements in introvert sectors 1,2 , and 7 to 10 . In these sectors, the sector-wise scalid arrangement was similar to the one of $C$. shirleyi, as redescribed by Neuhaus et al. (2019). A total of eight trichoscalids, each 
flanked by a pair of filamentous appendages, were observed. If the introvert follows the usual symmetry introvert patterns, this would sum up to fourteen in total.

The neck has sixteen placids (Figs. 5A, B, 6C, D): the midventral placid is broadest, measuring $12 \mu \mathrm{m}$ in width at its base; other placids are either broad ( $10 \mu \mathrm{m}$ wide) or narrow ( $6 \mu \mathrm{m}$ wide); broad and narrow placids alternate, except in ventromedial positions, where two narrow placids are located next to each other (Fig. 7F). The midventral placid has three knobby projections posteriorly on its exterior surface, and two more anterior ones that project from the placid; other broad placids have two projections on exterior surface and two anterior projecting ones, whereas narrow placids have a single projection on their exterior surface only.

The trunk is triangular in cross-section, with segment 1 consisting of a closed ring, segments 2 to 10 composed of one tergal and two sternal plates, and 11 of one tergal and one sternal plate. The cuticular ornamentation on segments 2 to 11 is divided into three transverse zones: 1) a narrow anterior zone with irregular, longitudinal lines or wrinkles, and a reticulated network near the midventral articulation, 2) a broad median zone densely covered with cuticular hairs, and 3) a short posterior zone (representing the free flap) with more regularly arranged longitudinal lines (Fig. 7E-L). Segment 1 has only two zones, an anterior with hair, representing about $3 / 4$ of the segment, and a free flap posteriorly (Fig. 7E, F). Cuticular hairs are small, triangular scales covering the entire transverse zones, except for hairless patches in laterodorsal and ventromedial positions on segments 2 to 10 , representing muscle attachment sites; ventromedial muscle attachment sites on anterior segments with reticulated substructure that becomes more indistinct and eventually disappears from segment 6. All posterior segment margins of segments 2 to 9 , and margins of tergal plates of segments 1 and 10, are fringed with small, characteristic flower-like extensions (Fig. 6C, I, 7J); posterior margin of sternal plate on segment 1 with fine acicular fringe tips, whereas sternal plates of segment 10 have no conspicuous fringe at all. Additional long, filiform fringes are present around the middorsal and lateroventral spines on segments 2 to 8 (Fig. 7G).

Segment 1 with middorsal and lateroventral acicular spines (Figs. 5A, B, 6C, D, 7E, F). Acicular spines on this and all following segments consist of a short, smooth base, and an end-piece densely covered with minute hairs. Tufts of short hairs emerge anterior to the acicular spines. Sensory spots type 6 are present as one paradorsal, one subdorsal, two laterodorsal and one ventromedial pair; sensory spots on the tergal plate near anterior segment margin; those on the sternal plate are in the posterior part of the hairy zone.

Segment 2 with middorsal and lateroventral acicular spines, and ventrolateral cuspidate spines (Figs. 5A, B, 6C, D, 7E, F); base of lateroventral acicular spines on this and all following segments flanked by tuft of short filamentous hairs. Sensory spots type 6 present in paradorsal, subdorsal, laterodorsal and ventromedial positions; all sensory spots on this and following eight segments are located in the intersection between the transverse hairy zone and the free flap.

Segment 3 with middorsal and lateroventral acicular spines. Sensory spots type 6 present in subdorsal, laterodorsal and ventromedial positions (Figs. 5A, B, 6C, D).

Segment 4 with middorsal and lateroventral acicular spines. Sensory spots type 6 present in paradorsal, subdorsal, and ventromedial positions (Figs. 5A, B, 6F).

Segment 5 with middorsal and lateroventral acicular spines, and ventrolateral cuspidate spines. Sensory spots type 6 present in paradorsal, subdorsal, and laterodorsal positions (Figs. 5A, B, 6E, F, 7G, H).
Segment 6 with middorsal and lateroventral acicular spines. Sensory spots type 6 present in paradorsal, subdorsal, laterodorsal and ventromedial positions (Figs. 5A, B, 6E, F, 7G, H).

Segment 7 similar with segment 6 in males (Figs. 5C and 7I, J). Stage 1 females additionally with a pair of protuberant appendages in ventromedial positions, anterior to, and more lateral than sensory spots (Fig. 5B).

Segment 8 with middorsal and lateroventral acicular spines, and lateral accessory cuspidate spines. Sensory spots type 6 present in paradorsal, subdorsal and ventromedial positions (Figs. 5A, B, 6G, $\mathrm{H}, 7 \mathrm{I}, \mathrm{J}$ ). Stage 1 females additionally with a pair of protuberant appendages in ventromedial positions, anterior to, and more midventral than sensory spots (Figs. 5B and $6 \mathrm{H}$ ).

Segment 9 with middorsal and lateroventral acicular spines, and ventrolateral cuspidate spines. Sensory spots type 6 present in paradorsal, subdorsal, laterodorsal and ventromedial positions (Figs. 5, 6G, H, 7K, L). Nephridiopore marked with tuft of minute papillae, present next to laterodorsal sensory spots (closer to subdorsal position) (Fig. 7K). Stage 1 females with ventromedial areas of densely set micropapillae (Figs. 5B and 6H).

Segment 10 with thin acicular spines in middorsal and laterodorsal positions in males and stage 1 females. Sensory spots type 6 present in subdorsal and lateroventral positions, and glandular cell outlets in ventromedial positions, present in both sedxes (Figs. 5 and 6I, J, L, M, 7K, L).

Segment 11 with midterminal and lateral terminal accessory spines (Figs. 5, 6A, B). Sensory spots type 3 present near and protruding beyond posterior segment margin in paradorsal and ventrolateral positions (Figs. $6 \mathrm{~J}$ and $7 \mathrm{~L}$ ). Females with gonopores in ventrolateral positions, anterior on segment (Fig. 6J).

\subsubsection{Notes on Condyloderes cf. C. flosfimbriatus from California}

Two additional specimens, very similar to $C$. flosfimbriatus sp. nov. were found in the deep-sea samples from California. The specimens have the same distribution of spines and sensory spots as the type specimens from the Gulf of Mexico, and they also have the characteristic flower-like fringes on the posterior segment margin. They differ slightly in two details though. The flower-like fringes are not present on the tergal plate of segment 1 . Instead the posterior margin of both the tergal and sternal plates form large, irregular, tooth-like extensions of different sizes (Fig. 6K). This trait can be observed in both the LM and SEM specimen. The LM specimen from St. Cal-4 furthermore tends to have spines being from $25 \%$ and up to $54 \%$ longer in both the dorsal and the lateral series (Table 4). Also the lateral terminal accessory and midterminal spines are $25 \%$ longer in the Californian specimen, but the proportions between lateral terminal accessory and midterminal spines are the same for the two populations (around 48\%). Due these subtle differences, and the geographic distance between the localities, the Californian population might represent another new species of Condyloderes. However, because of the shortage of specimens, and the possibility that deep-sea kinorhynchs cover a greater distributional range than other kinorhynchs, it cannot be excluded that these specimens represent a second population of C. florifimbriatus sp. nov., showing a certain degree of variation from the Gulf of Mexico specimens. Due to this uncertainty, we will for now treat them as Condyloderes cf. C. flosfimbriatus sp. nov.

\subsubsection{Notes on diagnostic and taxonomic features in $\mathrm{C}$.} flosfimbriatus sp. nov.

With cuspidate spines on segments $2,5,8$ and 9, C. flosfimbriatus sp. nov. is easily distinguished from most other congeners. However, its spine pattern is identical to the one in C. multispinosus though (McIntyre 1962; Neuhaus et al. 2019; Dal Zotto et al. 2019), 

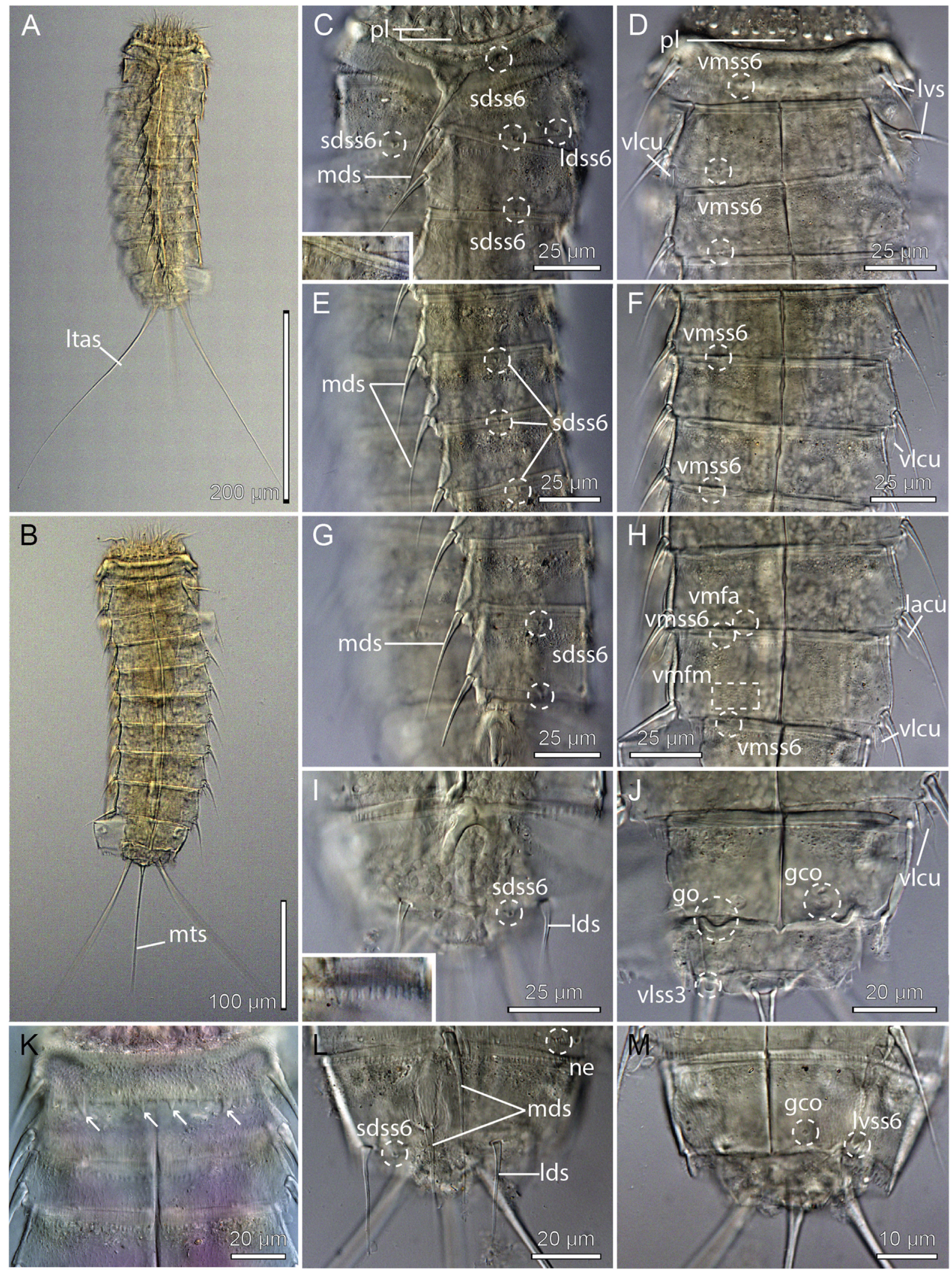

Fig. 6. Light micrographs showing overviews and details of Condyloderes flosfimbriatus sp. nov. (A-J) Female stage 1 holotype, NHMD-286561. (K) Condyloderes cf. C. flosfimbriatus sp. nov. from St. Cal-4, NHMD-288257. (L-M) Male paratype, NHMD-288247. (A) Dorsal overview. (B) Ventral overview. (C) Segments 1 to 4, dorsal view, inset shows posterior segment margin of segment 2. (D) Segments 1 to 3, ventral view. (E) Segments 5 to 7, dorsal view of right side (left side out of focus). (F) Segments 4 to 6, ventral view. (G) Segments 8 to 9, dorsal view of right side (left side out of focus). (H) Segments 8 to 9, ventral view, showing female morphology. (I) Segment 10, dorsal view, showing female morphology; inset shows posterior segment margin of segment 9. (J) Segments 10 to 11, ventral view, showing female morphology. (K) Segments 1 to 4 in Californian specimen, note irregular, rough serration of posterior segment margin of segment 1 (arrows). (L). Segments 10 to 11, dorsal view, showing male morphology. (M) Segments 10 to 11, ventral view, showing 
which complicates the taxonomy and distinction between the two species. Neuhaus et al. (2019) provided a detailed redescription of male C. multispinosus, and Dal Zotto et al. (2019) supplemented this with the first detailed account on female $C$. multispinosus morphology. This enables a straight forward comparison of the two species, and following differences were noted: The posterior segment margins in $C$. multispinosus have thin, acicular fringe tips, similar with those described from $C$. rohalorum sp. nov. (see, e.g., Fig. 4D-M), but very different from the flower-like fringes in C. flosfimbriatus sp. nov. This trait is very easily observed, and the posterior segment margins of C. multispinosus are welldocumented by Neuhaus et al. (2019). Condyloderes multispinosus furthermore has a broad indentation in the posterior segment margin of segment 1, spanning between the ventromedial positions, and no fringe-like structures are present all along this indentation. Conversely, C. flosfimbriatus sp. nov. has no, or only a very weak indentation (Fig. 7F), and minute acicular fringe-tips are present along the ventral side of segment 1 . There are furthermore some minor differences in distribution of sensory spots: C. multispinosus has laterodorsal sensory spots on segment 8 , whereas such sensory spots are absent in C. flosfimbriatus sp. nov.; sensory spots on the tergal plate of segment 1 are located medially on the segment in C. multispinosus, whereas they are located very close to the anterior segment margin in $C$. flosfimbriatus sp. nov.; and $C$. multispinosus has two pairs of laterodorsal sensory spots on segment 2 , whereas only a single pair is present in $C$. flosfimbriatus sp. nov. The spines in $C$. multispinosus are generally longer than those of $C$. flosfimbriatus sp. nov. in the Gulf of Mexico (middorsal spines are $15-38 \%$ longer, and lateroventral spines $26-37 \%$ longer), but they are quite close to the lengths of the spines in the Californian specimen. Conversely, lateral terminal accessory and midterminal spines are longer in C. flosfimbriatus sp. nov., but the proportions between these spines are the same for the two species.

These noteworthy, but still subtle, differences create a familiar dilemma: is $C$. multispinosus a species showing a relatively high degree of intraspecific morphological variation, and a very large distributional range, spanning from the Mediterranean and Northeast Atlantic to the Gulf of Mexico and the East Pacific? Or are there two, possibly three, closely related species with regional distributions? The optimal way to address the question would be through a comparative genetic approach, but without access to molecular sequences from any of the species/populations and no prospect of obtaining such sequences within the near future, the conclusions need to be based on morphological comparison. As recently learned from other cyclorhagid genera, a point has been reached where species boundaries cannot solely be based on the otherwise convenient spine-related characters. Analogous to the distinction between C. flosfimbriatus sp. nov. and C. multispinosus, the two congeners $C$. setoensis and C. paradoxus are also solely distinguished by minor differences in their distributions of sensory spots, and Neuhaus et al. (2019) considered whether the two species should be synonymized in the future. There are parallel examples in other kentrorhagid genera as well. For instance, two species of the closely related genus Centroderes are solely distinguished by differences in distribution of sensory spots (Neuhaus et al. 2014). The recently described species Semnoderes lusca Sørensen \& Landers, 2018 also shows close resemblance to its congener $S$. armiger Zelinka, 1928, and the two species cannot be distinguished by spine patterns, but only by spine morphology and cuticular ornamentation (Sørensen \& Landers 2018). In the same contribution, Sørensen \& Landers (2018) addressed at least two yet undescribed species of Antygomonas that are solely distinguished from each other and the known species A. paulae Sørensen, 2007 by spine dimensions.

In light of these recent findings, it is justified to consider C. flosfimbriatus sp. nov. as a distinct species, although it shows great resemblance with C. multispinosus. Undoubtedly, more examples of putatively different species of Condyloderes but with identical spine formulas will show up in the future, and it is therefore important to explore alternative diagnostic characters, and accept that spine patterns alone not always are sufficient to explain the species diversity.

\subsection{Condyloderes kurilensis Adrianov \& Maiorova, 2016}

\section{(Table 6)}

\subsubsection{Examined material}

Eight specimens of $C$. kurilensis were found in the Californian deep-sea samples. One male from St. Cal-4, one male and two stage 2 females from St. Cal-5, and one stage 2 female from St. Cal-6, all mounted in Fluoromount G, and deposited at NHMD under catalogue numbers NHMD-289331 to 289335 . Three additional specimens, two males and one stage 2 female, were collected at St. Cal-7, mounted for SEM and stored in the first author's personal reference collection. See Fig. 1 for localities and Table 1 for detailed station data.

\subsubsection{Comments on Condyloderes kurilensis}

The morphology of the collected specimens followed the redescription of C. kurilensis provided by Neuhaus et al. (2019) to such an extent that it is justified to conclude that they belong to this species. The spine patterns in all specimens were identical with those for $C$. kurilensis, and the metrics and dimensions were also within or very close to those in the original description (Adrianov \& Maiorova 2016), see Table 6. Sensory spot distribution could not be cross-checked completely in any of the specimens (in LM specimens some sensory spots were too indistinct, whereas the mounting prevented observation of some sensory spots in SEM specimens), but all sensory spots that could be observed, corresponded with the redescription provided by Neuhaus et al. (2019). The only exception was one SEM specimen that lacked laterodorsal sensory spots on segment 5 .

Since the species recently has been documented by Adrianov \& Maiorova (2016) and Neuhaus et al. (2019), and no significant new information can be provided, there is no need to provide any graphic documentation of the collected specimens. The most significant finding is the considerable extension of the species' distributional range. Until now, the species was only known from its type locality at the abyssal plain near the Kuril-Kamchatka Trench, east of Hokkaido, and southeast of the Kuril Islands. However, the present study's record of the species nearly the same latitude, but at the opposite side of the Pacific, and the simultaneous reporting of the species from the Clarion-Clipperton Fracture Zone in the tropical East Pacific (Sánchez et al. 2019b), suggest that C. kurilensis might exist in patchy populations across the abyssal plains of the North and Central Pacific.

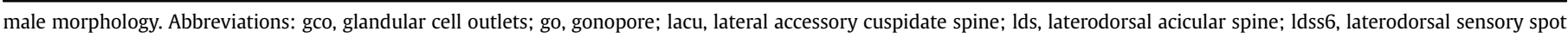

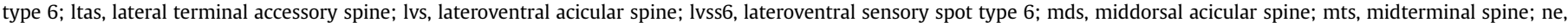

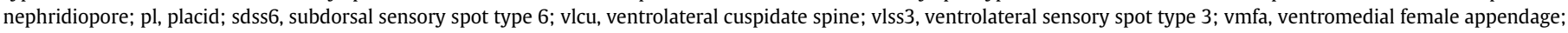
vmfm, ventromedial area of female micropapillae; vmss6, ventromedial sensory spot type 6 . 


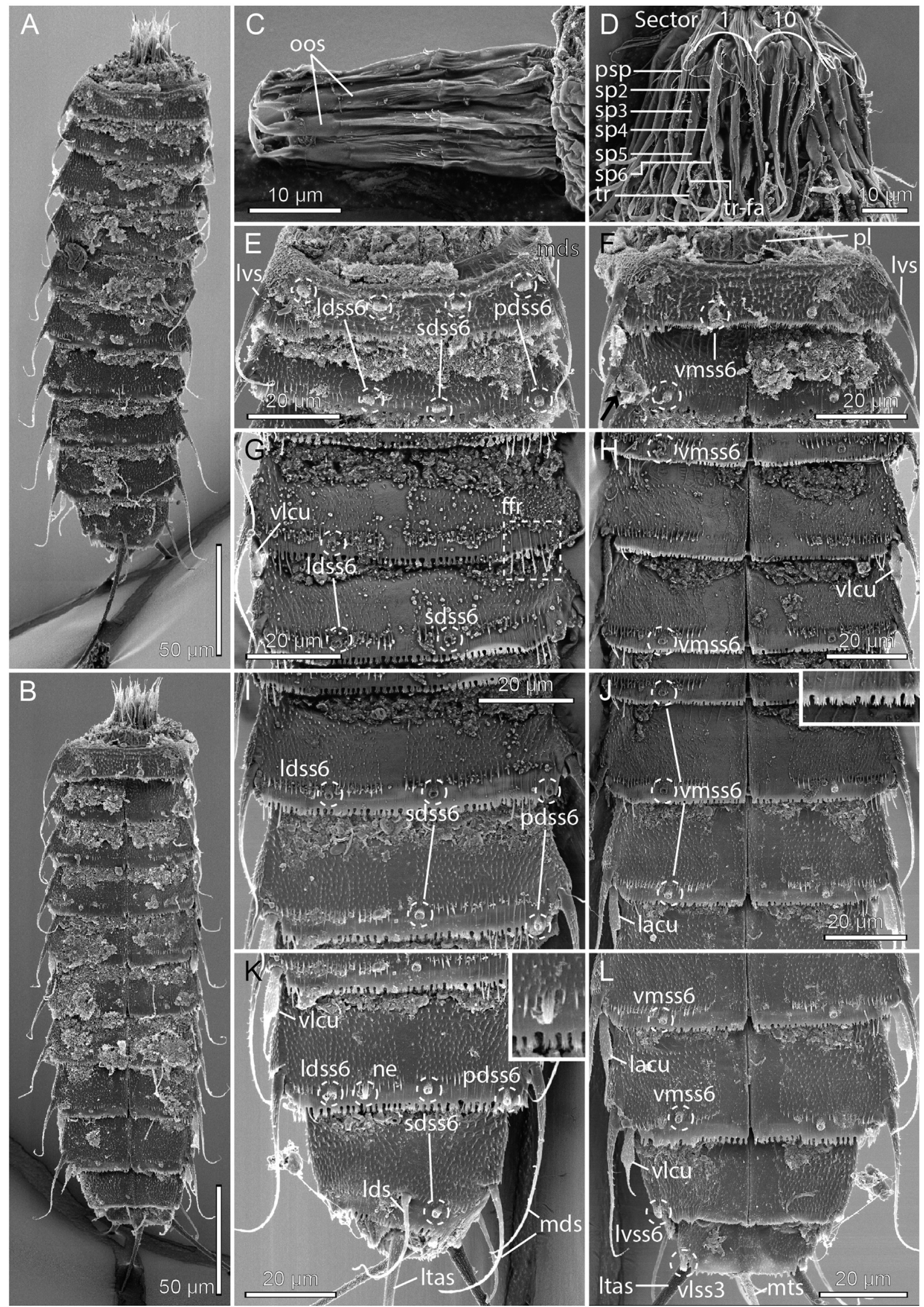

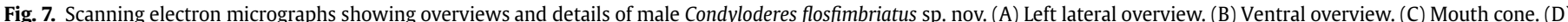

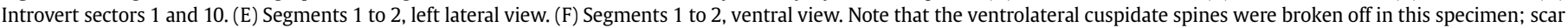




\subsection{Condyloderes sp. 1 from the Gulf of Mexico}

\section{(Fig. 8, Table 7)}

\subsubsection{Examined material}

A single male specimen was collected from mud on November 20, 2014, on St. GoM 74-2013 (Fig. 1, Table 1) at 187 m depth, south of the Florida Panhandle in the Gulf of Mexico $\left(29^{\circ} 49^{\prime} 13^{\prime \prime} \mathrm{N}\right.$, $086^{\circ} 59^{\prime} 06^{\prime \prime} \mathrm{W}$ ), mounted in Fluoromount G, and deposited at NHMD under catalogue number NHMD-286563.

\subsubsection{Short description of Condyloderes $s p .1$}

Station GoM 74-2013 yielded a single specimen that could not be assigned to any known species (Fig. 8). It may represent a new species, but since only a single specimen was available, and since the specimen might be immature, it is not described formally. Instead, an account on its morphology is provided, which hopefully will enable future studies to recognize the species, in case additional, conspecific specimens are found.

The species is relatively short and chubby (Fig. 8A), trunk length $=218 \mu \mathrm{m}$ (see all measurements in Table 7 ), and the trunk segments consists of a closed ring on segment 1 , a tergal and two sternal plates on segments 2 to 10 , and a tergal and a sternal plate on segment 11 . The neck has sixteen placid, with knobby projections: three projections on the broad midventral placid, two projections on other broad placids, and one projection on narrow placids.

Cuticular hairs are arranged in well-spaced, longitudinal stripes along most of the trunk (Fig. 8B-G), except for densely haired areas along the tergosternal junctions and the middorsal line. The composition of the posterior segment margins is difficult to observe, but they appear to be rather weakly defined, with thin acicular fringes.

Acicular spines are present in middorsal positions on segments 1 to 10 , in lateral accessory position on segment 1 , in lateroventral positions on segments 2 to 9, and in laterodorsal positions on segment 10. Cuspidate spines are present on segment 5 in ventromedial positions, but close to ventrolateral (Fig. 8E), on segment 8 in ventrolateral positions, and on segment 9 in sublateral positions (Fig. 8G). Midterminal and lateral terminal accessory spines are present, MTS/LTS ratio $=45.7 \%$.

Sensory spots type 6 are distributed as follows: paradorsally on segments 2 to 4,6 , and 8 to 9; subdorsally on segments 1 to 3,5 , and 10 ; laterodorsally on segments 1 to 2 (double pair on segment 2), and 5 to 9 (some sensory spots may have been overlooked in the dorsal series); ventromedially on segments 1 to 2, 4, and 6 to 9 . Sensory spots type 3 present in paradorsal and ventrolateral positions on segment 11.

The specimen is interpreted to be a male, based on the presence of middorsal and laterodorsal spines on segment 10 (Fig. 8F), and lack of female characters, i.e., gonopores and appendages on the sternal plates. However, neither mature testes nor spermatozoa were observed though, which could indicate that the specimen is not completely mature.

\subsubsection{Comments on Condyloderes sp. 1}

The general distribution of spines, and in particular the presence of ventromedial cuspidate spines on segment 5 , makes
Table 4

Measurements from light microscopy for female stage 1 holotype and male paratype of Condyloderes flosfimbriatus sp. nov. from the Gulf of Mexico, and of one Californian non-type identified as Condyloderes cf. C. flosfimbriatus sp. nov. (in $\mu \mathrm{m}$ ). Abbreviations: (ac): acicular spine; (cu): cuspidate spine; LA: lateral accessory; LD: laterodorsal; LTAS: lateral terminal accessory spine; LV: lateroventral; MD, middorsal; MSW-7: maximum sternal width, measured on segment 7 in this species; MTS: midterminal spine; S: segment lengths; SW-10, standard width, always measured on segment 10; TL: trunk length; VL: ventrolateral; - damaged structure impossible to measure.

\begin{tabular}{|c|c|c|c|}
\hline \multirow[t]{3}{*}{ Character } & \multirow{3}{*}{$\frac{\frac{\text { 1 Holotype }}{\text { NHMD-286561 }}}{\text { GoM 31-2014 }}$} & \multirow{3}{*}{$\frac{\frac{\text { ¿ Paratype }}{\text { NHMD-288247 }}}{\text { GoM 29-2014 }}$} & \multirow{3}{*}{$\frac{\frac{\delta \text { Non-type }}{\text { NHMD-288257 }}}{\text { Cal } 4}$} \\
\hline & & & \\
\hline & & & \\
\hline $\mathrm{TL}$ & 293 & 308 & 314 \\
\hline MSW-7 & 77 & 78 & 93 \\
\hline MSW-7/TL & $26.3 \%$ & $25.3 \%$ & $29.6 \%$ \\
\hline SW-10 & 57 & 57 & 71 \\
\hline SW-10/TL & $19.5 \%$ & $18.5 \%$ & $22.6 \%$ \\
\hline S1 & 29 & 25 & 35 \\
\hline S2 & 31 & 28 & 37 \\
\hline S3 & 31 & 30 & 37 \\
\hline S4 & 31 & 31 & 39 \\
\hline S5 & 33 & 32 & 42 \\
\hline S6 & 35 & 34 & 44 \\
\hline S7 & 37 & 36 & 44 \\
\hline S8 & 38 & 38 & 46 \\
\hline S9 & 42 & 43 & 52 \\
\hline S10 & 34 & 36 & 36 \\
\hline S11 & 21 & 21 & 34 \\
\hline MD1 (ac) & 34 & - & 43 \\
\hline MD2 (ac) & 33 & 32 & 45 \\
\hline MD3 (ac) & 38 & 39 & 48 \\
\hline MD4 (ac) & - & 38 & 52 \\
\hline MD5 (ac) & 39 & 41 & 53 \\
\hline MD6 (ac) & 39 & 40 & 54 \\
\hline MD7 (ac) & 43 & 45 & 57 \\
\hline MD8 (ac) & 44 & 48 & 55 \\
\hline MD9 (ac) & - & 49 & 74 \\
\hline MD10 (ac) & 29 & 27 & 56 \\
\hline LV1 (ac) & 34 & 36 & 45 \\
\hline LV2 (ac) & 32 & 39 & 44 \\
\hline VL2 (cu) & 16 & 16 & 20 \\
\hline LV3 (ac) & 34 & 41 & 42 \\
\hline LV4 (ac) & 34 & 36 & 48 \\
\hline LV5 (ac) & 37 & 38 & 47 \\
\hline VL5 (cu) & 18 & 18 & 20 \\
\hline LV6 (ac) & 38 & 41 & 55 \\
\hline LV7 (ac) & 39 & 38 & 56 \\
\hline LV8 (ac) & 40 & 45 & 61 \\
\hline LA8 (cu) & 20 & 21 & 26 \\
\hline LV9 (ac) & 46 & 49 & 71 \\
\hline VL9 (cu) & 17 & 17 & 25 \\
\hline LD10 (ac) & 29 & 33 & 38 \\
\hline MTS & 122 & 127 & 151 \\
\hline LTAS & 252 & 265 & 319 \\
\hline MTS/LTAS & $48.4 \%$ & $47.9 \%$ & $47.3 \%$ \\
\hline LTAS/TL & $86.0 \%$ & $86.0 \%$ & $101.6 \%$ \\
\hline
\end{tabular}

Condyloderes sp. 1 differ from all other species of Condyloderes known so far. Among previously described congeners, no others have cuspidate spines on segments 5, 8, and 9 only, and also their attachment points in the longitudinal series are unusual. In most, if not all previously known Condyloderes species with cuspidate spines on these segments, the spines on segments 5 and 9 would 
Table 5

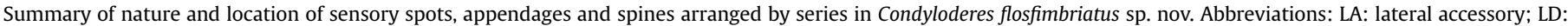

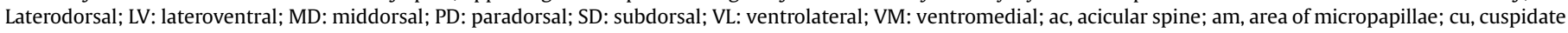

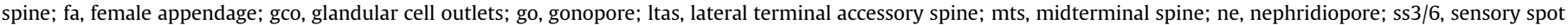
type 3/6; (\$1), female stage 1 condition of sexually dimorphic character; ( $₫$ ), male condition of sexually dimorphic character.

\begin{tabular}{|c|c|c|c|c|c|c|c|c|}
\hline $\begin{array}{l}\text { Position } \\
\text { Segment }\end{array}$ & MD & PD & SD & LD & LA & LV & VL & VM \\
\hline 1 & $\mathrm{ac}$ & ss6 & ss6 & ss6,ss6 & & ac & & ss6 \\
\hline 2 & ac & ss6 & ss6 & ss6 & & ac & $\mathrm{cu}$ & ss6 \\
\hline 3 & ac & & ss6 & ss6 & & ac & & ss6 \\
\hline 4 & $\mathrm{ac}$ & ss6 & ss6 & & & ac & & ss6 \\
\hline 5 & $\mathrm{ac}$ & ss6 & ss6 & ss6 & & ac & $\mathrm{cu}$ & \\
\hline 6 & ac & ss6 & ss6 & ss6 & & ac & & ss6 \\
\hline 7 & ac & ss6 & ss6 & ss6 & & ac & & fa (\$1),ss6 \\
\hline 8 & ac & ss6 & ss6 & & $\mathrm{cu}$ & ac & & ss6, fa (\$1) \\
\hline 9 & ac & ss6 & ss6 & ne,ss6 & & ac & $\mathrm{cu}$ & ss6,am (1) \\
\hline 10 & ac $\left(\$ 1,0^{\star}\right)$ & & ss6 & ac $\left(\$ 1,0^{\star}\right)$ & & ss6 & & gco \\
\hline 11 & $\mathrm{mts}$ & ss3 & & & ltas & & go $(\$ 1+2), s s 3$ & \\
\hline
\end{tabular}

attach in ventrolateral positions, whereas those on segment 8 would be lateral accessory (see, e.g., descriptions above and Neuhaus et al. 2019). In Condyloderes sp. 1 though, the cuspidate spines on segment 5 are so ventrally displaced that they attach in ventromedial positions (Fig. 8E). Those on segment 8 are ventrolateral, and on segment 9 there is so much space between the lateroventral acicular spine and the cuspidate spines, that the position of the latter must be interpreted as sublateral (Fig. 8G).

However, this unusual cuspidate spine pattern, combined with the displacement of the lateral spines on segment 1 to a lateral accessory position, corresponds perfectly with the pattern in a new Mediterranean species described by Dal Zotto et al. (2019), from the Ligurian Sea, off Livorno in Italy. The only conspicuous difference between Condyloderes sp. 1 and the new species of Dal Zotto et al. (2019) can be found in the pattern of their cuticular hairs - a character that Dal Zotto et al. (2019) highlights as taxonomically significant for their new species. The new Mediterranean species is characterized by the presence of uncommonly long and bushy cuticular hairs covering great parts of segments 1 to 9 . These long hairs are in particular evident in SEM (see SEM plates of Dal Zotto et al. 2019). Instead, Condyloderes sp. 1 appears to have very fine hairs, arranged in well-defined longitudinal lines. This trait represents a considerable difference from the hair covering in the new Mediterranean species, and we therefore find it too premature to suggest that the two species are conspecific. But it should be stressed, that all other similarities are striking, and it is not unlikely that the new Mediterranean species have a conspecific population, or at least a closely related species, in the Gulf of Mexico.

\subsection{Condyloderes sp. 2 from the Californian deep-sea}

(Fig. 9, Table 7)

\subsubsection{Examined material}

Two specimens were collected in the Californian deep-sea. One male specimen was collected from mud on September 21, 2008, on St. Cal-4 (Fig. 1, Table 1) at $2.733 \mathrm{~m}$ depth $\left(39^{\circ} 59^{\prime} 53^{\prime \prime} \mathrm{N}\right.$, $125^{\circ} 26^{\prime} 36^{\prime \prime} \mathrm{W}$ ), mounted in Fluoromount G, and deposited at NHMD under catalogue number NHMD-289336. Furthermore, a female stage 2 specimen was collected from mud on September 24 , 2008 , on St. Cal-6 (Fig. 1, Table 1) at $2.719 \mathrm{~m}$ depth $\left(36^{\circ} 40^{\prime} 52^{\prime \prime} \mathrm{N}\right.$, $\left.122^{\circ} 49^{\prime} 37^{\prime \prime} \mathrm{W}\right)$, mounted for SEM, and stored in the first authors personal reference collection.

\subsubsection{Short description of Condyloderes $s p .2$}

Another putatively new species, but represented by a very limited number of specimens, was found in the Californian deep-
Table 6

Measurements from light microscopy Condyloderes kurilensis (in $\mu \mathrm{m}$ ) from the Californian deep-sea, including number of measured specimens $(n)$ and standard deviation (SD). Abbreviations: (ac): acicular spine; (cu): cuspidate spine; LA: lateral accessory; LD: laterodorsal; LTAS: lateral terminal accessory spine; LV: lateroventral; MD, middorsal; MSW-7: maximum sternal width, measured on segment 7 in this species; MTS: midterminal spine; S: segment lengths; SW-10, standard width, always measured on segment 10; TL: trunk length; VL: ventrolateral.

\begin{tabular}{|c|c|c|c|c|}
\hline Character & $n$ & Range & Mean & SD \\
\hline $\mathrm{TL}$ & 5 & $333-414$ & 361 & 33.04 \\
\hline MSW-7 & 4 & $88-94$ & 92 & 2.71 \\
\hline MSW-7/TL & 4 & $22.5-27.4 \%$ & $25.1 \%$ & $2.04 \%$ \\
\hline SW-10 & 4 & $68-77$ & 72 & 4.24 \\
\hline SW-10/TL & 4 & $17.9-22.7 \%$ & $19.7 \%$ & $2.19 \%$ \\
\hline S1 & 5 & $25-35$ & 29 & 3.67 \\
\hline $\mathrm{S} 2$ & 5 & $32-37$ & 34 & 2.74 \\
\hline S3 & 5 & $33-39$ & 35 & 2.30 \\
\hline S4 & 5 & $38-41$ & 39 & 1.14 \\
\hline S5 & 5 & $39-46$ & 43 & 2.74 \\
\hline S6 & 5 & $39-50$ & 45 & 4.06 \\
\hline S7 & 5 & $44-50$ & 47 & 2.17 \\
\hline S8 & 5 & $46-56$ & 50 & 3.81 \\
\hline S9 & 5 & $48-61$ & 54 & 5.03 \\
\hline S10 & 5 & $43-52$ & 47 & 3.36 \\
\hline S11 & 5 & $28-32$ & 30 & 1.52 \\
\hline MD1 (ac) & 5 & $39-43$ & 42 & 1.67 \\
\hline MD2 (ac) & 5 & $37-44$ & 40 & 2.74 \\
\hline MD3 (ac) & 5 & $39-49$ & 42 & 3.85 \\
\hline MD4 (ac) & 5 & $37-52$ & 45 & 5.68 \\
\hline MD5 (ac) & 5 & $47-52$ & 49 & 2.59 \\
\hline MD6 (ac) & 5 & $47-54$ & 51 & 2.51 \\
\hline MD7 (ac) & 5 & $50-55$ & 53 & 2.49 \\
\hline MD8 (ac) & 5 & $58-64$ & 61 & 2.70 \\
\hline MD9 (ac) & 5 & $70-86$ & 81 & 6.32 \\
\hline MD10 (ac) & 2 & $40-46$ & 43 & 4.24 \\
\hline LV1 (ac) & 5 & $35-40$ & 37 & 1.92 \\
\hline LV2 (ac) & 4 & $33-39$ & 36 & 2.75 \\
\hline LV3 (ac) & 5 & $38-43$ & 41 & 2.17 \\
\hline LV4 (ac) & 5 & $40-44$ & 42 & 1.67 \\
\hline LV5 (ac) & 5 & $41-51$ & 45 & 3.67 \\
\hline VL5 (cu) & 5 & $18-33$ & 24 & 7.12 \\
\hline LV6 (ac) & 5 & $43-50$ & 48 & 2.92 \\
\hline LV7 (ac) & 5 & $47-51$ & 49 & 1.79 \\
\hline LV8 (ac) & 5 & $56-60$ & 58 & 1.82 \\
\hline LA8 (cu) & 5 & $24-30$ & 26 & 2.30 \\
\hline VL9 (cu) & 5 & $65-77$ & 73 & 4.76 \\
\hline LD10 (ac) & 2 & $40-43$ & 42 & 2.12 \\
\hline MTS & 5 & $100-131$ & 116 & 12.98 \\
\hline LTAS & 5 & $194-214$ & 205 & 8.53 \\
\hline MTS/LTAS & 5 & $49.3-63.6 \%$ & $56.6 \%$ & $6.81 \%$ \\
\hline LTAS/TL & 5 & $49.8-64.0 \%$ & $57.2 \%$ & $5.73 \%$ \\
\hline
\end{tabular}


sea (Fig. 9). The species has a trunk length of $301 \mu \mathrm{m}$, but the lateral terminal accessory spines exceed the trunk length, LTAS/TL ratio $=105 \%$ (see all measurements in Table 7 ). It has the knobby placids and a segment composition typical for species of Condyloderes. The LM specimen (Fig. 9A-C) was mounted in a way that only allowed close examination of cuticular structures on the ventral side, whereas the SEM specimen (Fig. 9D-H) rested on its ventral side, hence only allowing observation of structures on the tergal plates. However, based on the identical spine patterns in the two specimens, they are considered conspecific, and a full overview of cuticular structures can therefore be provided when observations from both are summarized.

Cuticular hairs are minute, triangular scales, covering the segments. The posterior segment margins of segments 2 to 10 form the same flower-like extensions that were described for $C$. flosfimbriatus (see description above, see section 3.2.4) (Fig. 9B-H), whereas the margins of segment 1 form irregular tooth-like projections (Fig. 9A, D), very similar to those in C. kurilensis.

The male has acicular spines in middorsal positions on segments 1 to 10 , in lateroventral positions on segments 1 to 9 , and in laterodorsal positions on segment 10 . The stage 2 female has a similar spine pattern, except on segment 10 that is devoid of spines (Fig. 9H). Both sexes have cuspidate spines on segments 4 and 8 in lateral accessory positions (Fig. 9A, C, E, G), and on segments 2, 5, and 9 in ventrolateral positions (Fig. 9A-D, G). Midterminal and lateral terminal accessory spines are present, MTS/LTS ratio $=47.8 \%$.

Sensory spots type 6 are distributed as follows: Paradorsally on segments 2, 4 to 6 , and 8 to 9; subdorsally on segments 1 to 10 (double pair on segment 1); laterodorsally on segments 1 to 3 (double pair on segment 1), 5 to 7 , and on 9 (next to nephridiopore); and ventromedially on segments 1 to 4 and 6 to 9 . Sensory spots type 3 present in paradorsal and ventrolateral positions on segment 11.

The LM specimen is interpreted as a male due to the presence of spines on segment 10 , and lack of female characters, i.e., gonopores and appendages on the sternal plates. Likewise, the SEM specimen is considered to be a stage 2 female due to the lack of spines on segment 10 , but it should be stressed that it was impossible to confirm the presence of female characters on the ventral side of the specimen.

\subsubsection{Comments on Condyloderes sp. 2}

The presence of cuspidate spines on segments $2,4,5,8$, and 9 makes the spine pattern in Condyloderes sp. 2 similar to the patterns in C. paradoxus and C. setoensis (Higgins, 1969; Adrianov et al., 2002; Neuhaus et al., 2019). However, the distribution of sensory spots differs slightly between the species, i.e.: Condyloderes sp. 2 has five pairs of tergal sensory spots on segment 1 , versus four pairs in C. setoensis; Condyloderes sp. 2 has three pairs of tergal sensory spots on segment 2 , versus four pairs in C. paradoxus and C. setoensis; Condyloderes sp. 2 has two pairs of tergal sensory spots on segment 8 , versus three pairs in C. paradoxus; and, Condyloderes sp. 2 lacks ventromedial sensory spots on segment 5 , whereas such sensory spots are present in both $C$. paradoxus and C. setoensis. Condyloderes sp. 2 furthermore differs from the two Asian species in its appearance of posterior
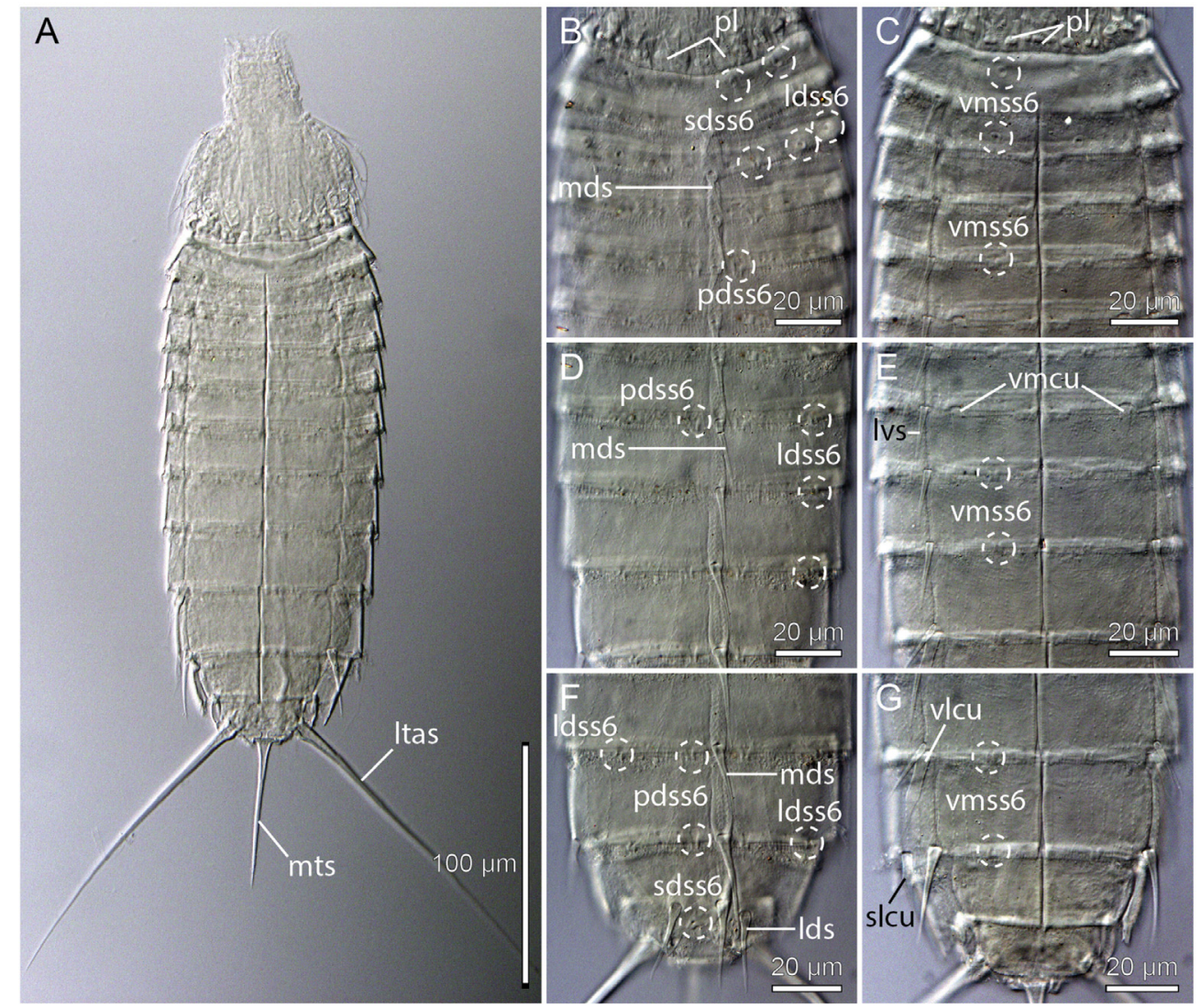

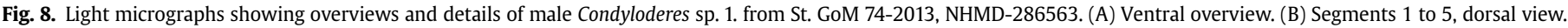

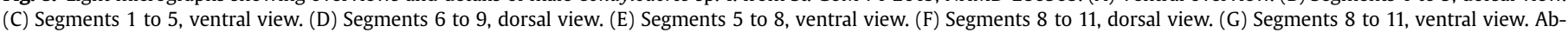

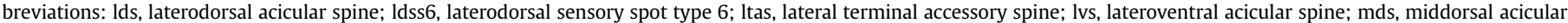

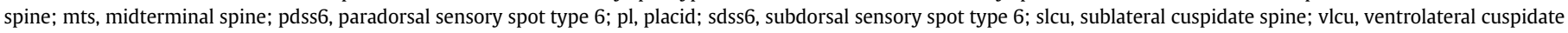
spine; vmcu, ventromedial cuspidate spine; vmss6, ventromedial sensory spot type 6 . 
Table 7

Measurements from light microscopy for two putatively new species, Condyloderes sp. 1 and Condyloderes sp. 2 from the Gulf of Mexico and Californian deep-sea, respectively (in $\mu \mathrm{m}$ ). Abbreviations: (ac): acicular spine; (cu): cuspidate spine; LA: lateral accessory; LD: laterodorsal; LTAS: lateral terminal accessory spine; LV: lateroventral; MD, middorsal; MSW-7: maximum sternal width, measured on segment 7 in both species; MTS: midterminal spine; S: segment lengths; SL: sublateral; SW10, standard width, always measured on segment 10; TL: trunk length; VL: ventrolateral; VM: ventromedial. N/A, non-applicable, structure not present in the species; - damaged structure impossible to measure.

\begin{tabular}{|c|c|c|}
\hline \multirow[t]{3}{*}{ Character } & \multirow{2}{*}{$\frac{o \text { C. sp. } 1}{\text { NHMD-286563 }}$} & \multirow{2}{*}{$\frac{o \text { C. sp. } 2}{\text { NHMD-289336 }}$} \\
\hline & & \\
\hline & GoM 74-2013 & Cal-4 \\
\hline $\mathrm{TL}$ & 218 & 301 \\
\hline MSW-7 & 65 & 90 \\
\hline MSW-7/TL & $29.8 \%$ & $29.9 \%$ \\
\hline SW-10 & 51 & 64 \\
\hline SW-10/TL & $23.4 \%$ & $21.3 \%$ \\
\hline S1 & 21 & 37 \\
\hline S2 & 26 & 39 \\
\hline S3 & 27 & 38 \\
\hline S4 & 27 & 45 \\
\hline S5 & 29 & 45 \\
\hline S6 & 32 & 46 \\
\hline S7 & 32 & 47 \\
\hline S8 & 34 & 46 \\
\hline S9 & 37 & 51 \\
\hline S10 & 32 & 42 \\
\hline S11 & 21 & 29 \\
\hline MD1 (ac) & 19 & - \\
\hline MD2 (ac) & 19 & - \\
\hline MD3 (ac) & 18 & 47 \\
\hline MD4 (ac) & 20 & 49 \\
\hline MD5 (ac) & 22 & 52 \\
\hline MD6 (ac) & 23 & 53 \\
\hline MD7 (ac) & 27 & 59 \\
\hline MD8 (ac) & 24 & - \\
\hline MD9 (ac) & 31 & 73 \\
\hline MD10 (ac) & 28 & 53 \\
\hline LV1 (ac) & 23 & 50 \\
\hline LV2 (ac) & 19 & 46 \\
\hline VL2 (cu) & N/A & - \\
\hline LV3 (ac) & 19 & 52 \\
\hline LV4 (ac) & 21 & 54 \\
\hline LA4 (cu) & $\mathrm{N} / \mathrm{A}$ & 18 \\
\hline LV5 (ac) & 22 & 54 \\
\hline VL5 (cu) & N/A & 23 \\
\hline VM5 (cu) & 15 & $\mathrm{~N} / \mathrm{A}$ \\
\hline LV6 (ac) & 19 & 53 \\
\hline LV7 (ac) & 20 & 58 \\
\hline LV8 (ac) & 20 & 63 \\
\hline LA8 (cu) & $\mathrm{N} / \mathrm{A}$ & 28 \\
\hline VL8 (cu) & 23 & $\mathrm{~N} / \mathrm{A}$ \\
\hline LV9 (ac) & 29 & 75 \\
\hline SL9 (cu) & 21 & $\mathrm{~N} / \mathrm{A}$ \\
\hline VL9 (cu) & $\mathrm{N} / \mathrm{A}$ & 21 \\
\hline LD10 (ac) & 24 & 50 \\
\hline MTS & 64 & 151 \\
\hline LTAS & 140 & 316 \\
\hline MTS/LTAS & $45.7 \%$ & $47.8 \%$ \\
\hline LTAS/TL & $64.2 \%$ & $105.0 \%$ \\
\hline
\end{tabular}

segment margins. Whereas the margins in $C$. paradoxus and C. setoensis have thin, acicular fringe tips, typical for a majority of the known Condyloderes species, Condyloderes sp. 2 have irregular, serrated margins on segment 1 , and flower-like extensions on segments 2 to 10 .

These difference, although subtle, suggest that Condyloderes sp. 2 represents a new species, but due to the limited material no formal description is provided. Hopefully the differential notes provided here will be helpful if the species is recorded again in the future.

\section{Discussion}

\subsection{Distribution patterns of deep-sea kinorhynchs}

A part of the present study is an offshoot from the recently published study of deep-sea Echinoderes from the US West Coast (Sørensen et al. 2018). This study described seven new species of Echinoderes, but it also showed, perhaps more surprisingly, that the deep-sea habitats included known species from very distant localities. Those records included Echinoderes hakaiensis Herranz et al., 2018, known from British Columbia, $1.400 \mathrm{~km}$ away, Fissuroderes higginsi Neuhaus \& Blasche, 2006, known from New Zealand, and Echinoderes unispinosus Yamasaki et al., 2018 known from the Northeast Atlantic (Neuhaus \& Blasche 2006; Herranz et al. 2018; Yamasaki et al. 2018a). In addition, Sánchez et al. (2019b) report the presence of $F$. higginsi, Echinoderes juliae (described in abovementioned study of Sørensen et al. 2018), and C. kurilensis from the tropical East Pacific. With the records of C. kurilensis from four deep-sea stations off California, we now have additional examples of a deep-sea kinorhynch with disjunct distribution or covering a very large continuous distributional range. This suggests that deepsea kinorhynchs may disperse over much larger distances than the majority of the continental species, as suggested by Sørensen et al. (2018).

However, there is also a different trend in the present study as well as the one of Sørensen et al. (2018), namely the occurrence of populations of kinorhynchs that are geographically separated, and also differ in a few minor morphological differences. Sørensen et al. (2018) described Echinoderes dubiosus Sørensen et al., 2018 that showed great resemblance with the northeast Atlantic deep-sea species Echinoderes bathyalis Yamasaki et al., 2018 (see Yamasaki et al. 2018b). In the present study C. flosfimbriatus sp. nov., described from the Gulf of Mexico, is likewise morphologically very close to the Northeast Atlantic and Mediterranean C. multispinosus (see McIntyre, 1962; Dal Zotto et al., 2019). Also observed are populations of a species similar to or conspecific with C. flosfimbriatus sp. nov. in the Californian deep-sea samples, and vice versa, specimens similar to or conspecific with the Californian C. rohalorum sp. nov. in the Gulf of Mexico. This combination of, on one hand, identical specimens with potentially great distributional ranges, and on the other, specimens showing minor differences that are correlated with their biogeography, blurs species boundaries and hence recognition of species. If only all kinorhynchs had a rather regionalized distribution, it would be straight forward to conclude that geographically separated specimens with slightly different morphology also represented different species. But knowing that kinorhynchs with huge distributional ranges probably do exist makes it difficult to distinguish between intraspecific variation and species boundaries. The obvious approach to solve the problem would be through genetic comparison of the different populations, but this is often impossible due to practical obstacles such as a low number of available specimens, or the material being formalinfixed long before they are made accessible for the taxonomic examination. Hence, it would be desirable if the problem could be solved with a morphological approach, but it is currently difficult to point out suitable, objective characters. Spine patterns are not always sufficient to distinguish closely related species, sensory spot distribution is occasionally used (though they may vary at the individual level), and our understanding of metric characters is still rather limited. Future studies including both comprehensive molecular data and detailed morphological information could perhaps be the key to identify the taxonomically significant characters amongst closely related but geographically vicariant populations. 

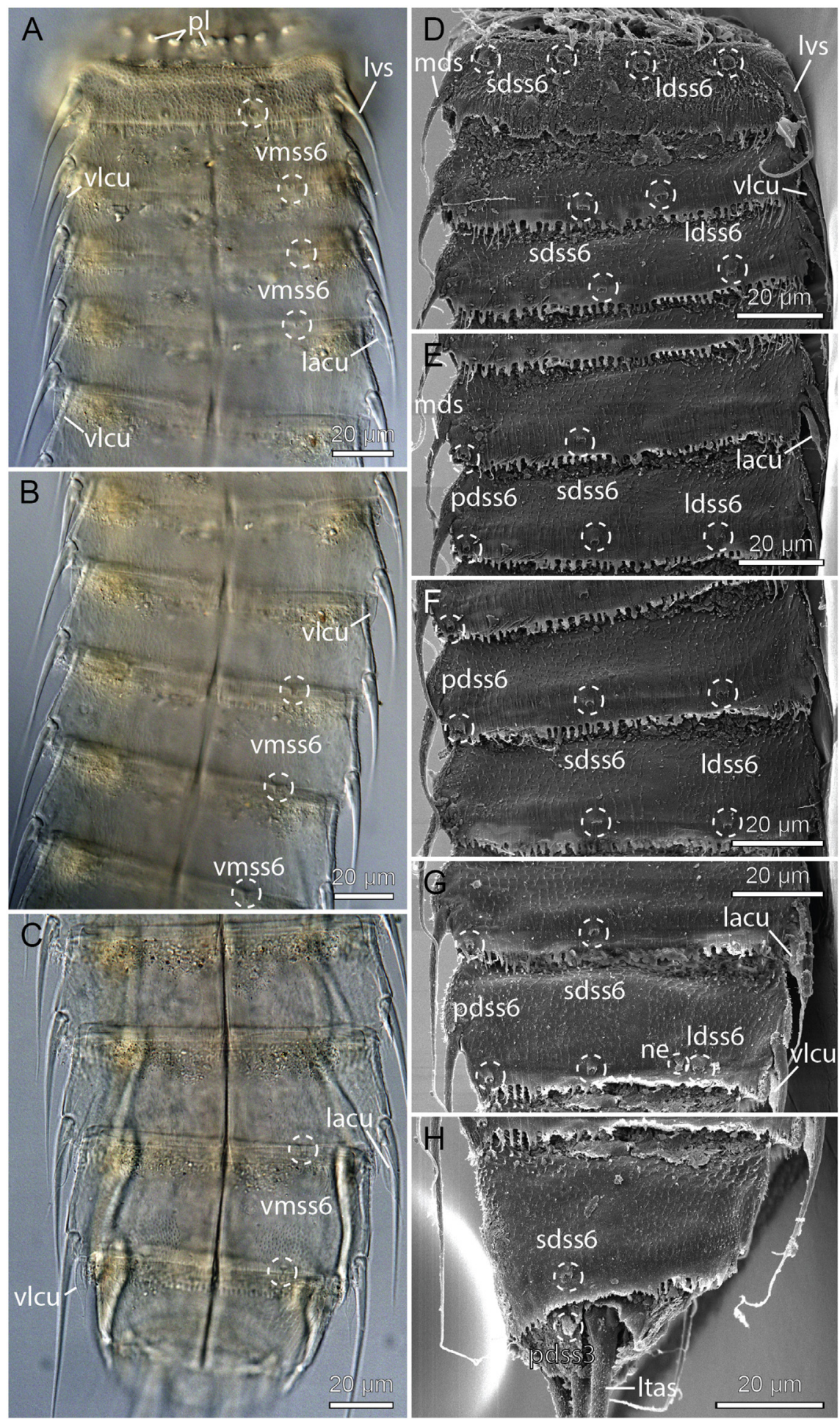

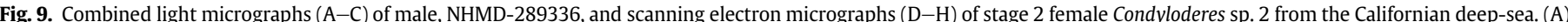

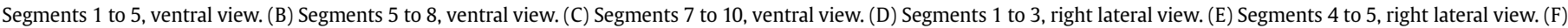

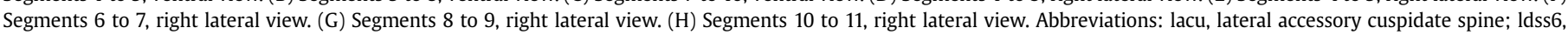

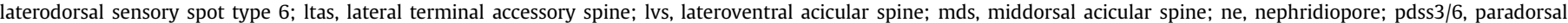
sensory spot type 3/6; pl, placid; sdss6, subdorsal sensory spot type 6; vlcu, ventrolateral cuspidate spine; vmss6, ventromedial sensory spot type 6 .

Despite the highlighted challenges, the present study stresses that exploration of the kinorhynch deep-sea fauna increases our knowledge of kinorhynch biodiversity. It also provides new information about kinorhynch distribution patterns and shows that some deep-sea species have much larger distributional ranges than the more regionalized continental species.

\subsection{Female dimorphism and indications of adult moulting}

Correct determination of sexes in species of Condyloderes has apparently been a challenge so far, and as shown by Neuhaus et al. (2019) all species descriptions, except those of C. kurilensis, C. storchi, and C. shirleyi, have involved some degree of sex 
C. paradoxus

C. florifimbriatus sp. nov.

C. kurilensis

C. setoesis

C. shirleyi

C. sp. 2 St. Cal-4+6
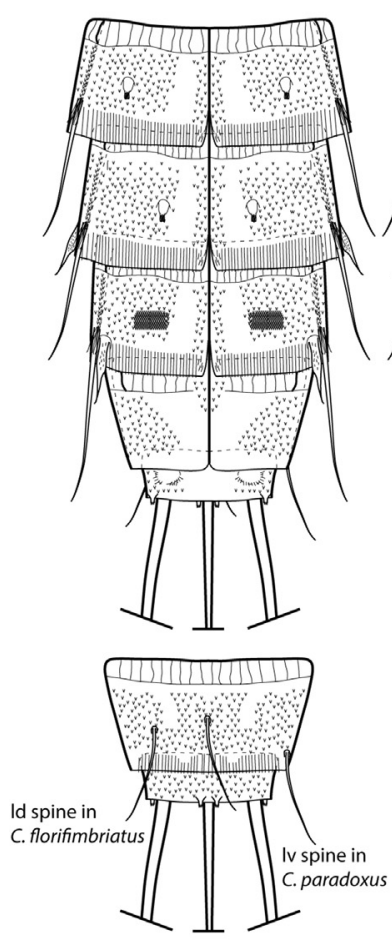

O stage 1
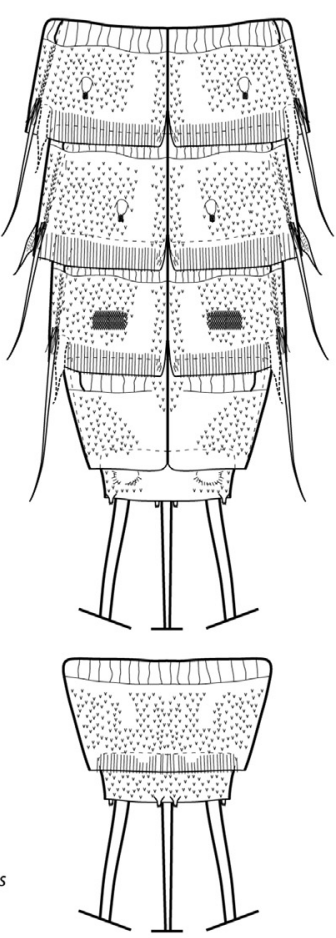

Ostage 2
C. rohalorum sp. nov.
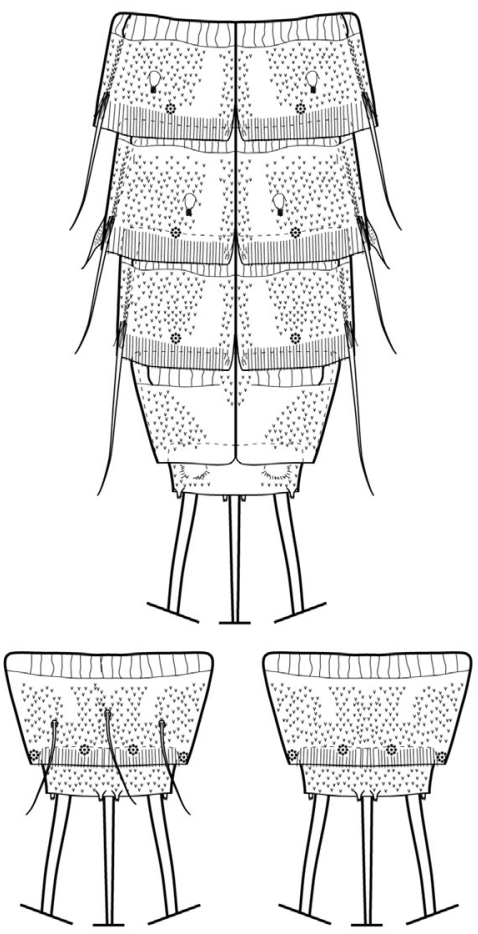

O stage 1
O stage 2

Fig. 10. Diagrammed presentation of currently known female stages in species of Condyloderes.

misidentification. This confusion is to some degree due to the fact that sexual dimorphism expressed in spine distribution differs between species of Condyloderes, and that the only consistent female specific characters, i.e. gonopores and ventromedial appendages, were neglected in the first species descriptions.

According to Dal Zotto et al. (2019) the only consistently occurring female specific characters in species of Condyloderes are the presence of gonopores and ventromedial appendages on two or three segments from 5 to 8 . This conclusion is confirmed by the present study. Another potential female character, suggested by Neuhaus et al. (2019), is the presence of ventromedial micropapillae on segment 9 . However, such patches of micropapillae are lacking in female stages of $C$. rohalorum sp. nov., which demonstrates that it is not a general sex distinguishing character for all species of the genus. Also Dal Zotto et al. (2019) confirm the absence of such patches in females of their newly described species.

One additional sexually dimorphic character that exists in some, but not all, species is the spine pattern of segment 10 (Fig. 10). All known male Condyloderes, independent of species, have middorsal and laterodorsal acicular spines on segment 10 . Such spines are missing in females of $C$. kurilensis, $C$. setoensis, $C$. shirleyi, and Condyloderes sp. 2 from the present study (Adrianov \& Maiorova 2016; Neuhaus et al. 2019, present study). Furthermore, Dal Zotto et al. (2019) also confirmed the absence of segment 10 spines in females of $C$. multispinosus. Conversely, middorsal and laterodorsal spines (i.e., the condition typical for males) are present in females of C. flosfimbriatus sp. nov., and in middorsal and lateroventral positions in females of $C$. paradoxus and two newly described Mediterranean species (Neuhaus et al. 2019; Dal Zotto et al. 2019).
Interestingly, C. rohalorum sp. nov. turned out to have two different kinds of females, one with and one without spines on segment 10 , suggesting that two adult female stages exist for this species (Fig. 10). This resembles the condition in certain species of the closely related genus Centroderes. Neuhaus et al. (2014) demonstrated that two adult female stages exist at least for Centroderes drakei Neuhaus et al., 2014 and Centroderes spinosus (Reinhard, 1881), and that the earliest stage would have middorsal and laterodorsal spines on segment 10 , and subsequently moult into a second stage without such spines. Even without having observed the similar condition in Condyloderes, Neuhaus et al. (2019) already speculated whether morphologically different adult stages could be present in this genus as well. The finding of two adult female stages in C. rohalorum sp. nov. confirms that this is actually the case.

So far, the presence of female dimorphism has only been documented for $C$. rohalorum sp. nov., but it likely exists for other congeneric species as well. For instance, female morphology is still unknown for C. storchi, and with only very few (i.e. < 10) available female specimens for $C$. flosfimbriatus sp. nov., $C$. paradoxus, and C. kurilensis it is likely that more adult female stages could exist for these species. On the other hand, Neuhaus et al. (2019) studied fairly large numbers of specimens of $C$. setoensis and $C$. shirleyi, without finding adult female dimorphism, which suggests that females of those species only have one adult stage. This is not different from the situation in Centroderes where the number of adult stages also seems to differ between the species (Neuhaus et al. 2014).

Hence, based on the present findings, females of $C$. rohalorum sp. nov. possess two different adult stages, as it is the case with 
C. drakei and C. spinosus. The possible presence of several adult stages should be considered when working with this genus in the future. With this in mind, it might also reduce the risk of confusing genders as it occurred in older contributions.

Knowing that two adult female stages are present in C. rohalorum sp. nov. also leads to speculation whether adult moulting occurs within this species. Adult moulting has previously been documented for species of Campyloderes and Centroderes (Neuhaus \& Sørensen, 2013; Neuhaus et al., 2014), and even though direct evidence from a female Condyloderes that was fixed during moulting was not obtained, the presence of two adult stages strongly indicates that C. rohalorum sp. nov. has the same capabilities.

\section{Conclusions}

Two new species of Condyloderes were described, bringing the number of species in the genus up to ten - inclusive the two recently described species by Dal Zotto et al. (2019). The record of C. kurilensis (so far only known from the rim of the Kuril-Kamchatka Trench only) in the Californian deep-sea samples (as well as in the tropical East Pacific (see Sánchez et al. 2019b)) confirmed previous suggestions about deep-sea kinorhynchs covering a much larger distributional range than continental kinorhynchs. The study furthermore uncovered the first example of adult, female dimorphism amongst species of Condyloderes, previously known from species of Centroderes only. This finding suggests that other species of Condyloderes also might have more adult stages, indicating that adult moulting might take place within species of the genus.

\section{Acknowledgements}

Sampling off the US west coast was done with support of the United States National Science Foundation under grant number 0727243 to DT. Additionally, this research was made possible by a grant from The Gulf of Mexico Research Initiative (to SCL and MVS). Data are publicly available through the Gulf of Mexico Research Initiative Information \& Data Cooperative (GRIIDC) at https://data. gulfresearchinitiative.org (doi: 10.7266/N74J0C32 and 10.7266/ N7SB43S2). We are grateful to M. Rohal, E. E. Easton, C. Armstrong, S. Bode, S. Bourgoin, M. Bublitz, E. Carroll, R. Carvalho, R. Coker, V. Cruz, E. Darrow, S. Dorado, J. Fields, L. E. Gilles, A. S. McInnes, R. Rowland, F. Stephenson, L. Rose, and G. D. F. Wilson who all helped at sea or in the laboratory during sorting or processing of the US west coast material, and to the staff and students of Troy University for help with sediment collection and sample processing of the Gulf of Mexico material. Finally we would like to thanks the reviewers, N. Sánchez and M. Dal Zotto, for their valuable suggestions and comments to the manuscript.

\section{References}

Adrianov, A.V., Maiorova, A.S., 2016. Condyloderes kurilensis sp. n. (Kinorhyncha: Cyclorhagida) - a new deep water species from the abyssal plain near the KurilKamchatka Trench. Russ. J. Mar. Biol. 1, 11-19. https://doi.org/10.1134/ s1063074016010028.

Adrianov, A.V., Murakami, C., Shirayama, Y., 2002. Taxonomic study of the Kinorhyncha in Japan. II. Condyloderes setoensis, a new species (Kinorhyncha: Cyclorhagida) from Tanabe bay (Honshu Island), Japan. Proc. Biol. Soc. Wash. $115,205-216$.

Burgess, R., 2001. An improved protocol for separating meiofauna from sediments using colloidal silica sols. Mar. Ecol. Prog. Ser. 214, 161-165.

Dal Zotto, M., Neuhaus, B., Yamasaki, H., Todaro, A., 2019. The genus Condyloderes (Kinorhyncha: Cyclorhagida) in the Mediterranean Sea, including the description of two new species with novel characters. Zool. Anz. 282, 206-231. https:// doi.org/10.1016/j.jcz.2019.05.006.

Herranz, M., Yangel, E., Leander, B., 2018. Echinoderes hakaiensis sp. nov.: a new mud dragon (Kinorhyncha, Echinoderidae) from the northeastern Pacific Ocean with the redescription of Echinoderes pennaki Higgins, 1960. Mar. Biodivers. 48, 303-325. https://doi.org/10.1007/s12526-017-0726-z.
Higgins, R.P., 1969. Indian ocean Kinorhyncha: 1, Condyloderes and Sphenoderes, new cyclorhagid genera. Smithsonian Contrib. Zool. 14, 1-13.

Landers, S.C., Sørensen, M.V., 2016. Two new species of Echinoderes (Kinorhyncha, Cyclorhagida), E. romanoi sp. n. and E. joyceae sp. n., from the Gulf of Mexico. ZooKeys 594, 51-71. https://doi.org/10.3897/zookeys.594.8623.

Landers, S.C., Sørensen, M.V., 2018. Echinoderes sylviae n. sp. (Kinorhyncha, Cyclorhagida), from the Gulf of Mexico, with comparative notes on a similar species Echinoderes spinifurca. Bull. Mar. Sci. 94, 1499-1514. https://doi.org/10.5343/ bms.2017.1167.

Landers, S.C., Sørensen, M.V., Beaton, K.R., Jones, C.M., Miller, J.M., Stewart, P.M., 2018. Kinorhynch assemblages in the Gulf of Mexico continental shelf collected during a two-year survey. J. Exp. Mar. Biol. Ecol. 502, 81-90. https://doi.org/10. 1016/j.jembe.2017.05.013.

Landers, S.C., Sørensen, M.V., Sánchez, N., Beaton, K.R., Miller, J.M., Ingels, J., 2019. Kinorhynch communities on the Louisiana continental shelf. Proc. Biol. Soc. Wash. 132, 1-14. https://doi.org/10.2988/18-00008.

Martorelli, S., Higgins, R.P., 2004. Kinorhyncha from the stomach of the shrimp Pleoticus muelleri (bate, 1888) from Comodoro Rivadavia, Argentina. Zool. Anz. 243, 85-98.

McIntyre, A.D., 1962. The class Kinorhyncha (Echinoderida) in British waters. J. Mar. Biol. Assoc. U. K. 42, 503-509.

Neuhaus, B., Blasche, T., 2006. Fissuroderes, a new genus of Kinorhyncha (Cyclorhagida) from the deep sea and continental shelf of New Zealand and from the continental shelf of Costa Rica. Zool. Anz. 245, 19-52.

Neuhaus, B., Dal Zotto, M., Yamasaki, H., Higgins, R.P., 2019. Revision of Condyloderes (Kinorhyncha, Cyclorhagida) including description of Condyloderes shirleyi sp. nov. Zootaxa 4561, 1-91. https://doi.org/10.11646/zootaxa.4561.1.1.

Neuhaus, B., Pardos, F., Sørensen, M.V., Higgins, R.P., 2014. New species of Centroderes (Kinorhyncha: Cyclorhagida) from the Northwest Atlantic ocean, life cycle, and ground pattern of the genus. Zootaxa 3901, 1-69. http://www. mapress.com/zootaxa/2014/s/zt03901 069.pdf.

Neuhaus, B., Sørensen, M.V., 2013. Populations of Campyloderes sp. (Kinorhyncha, Cyclorhagida): one global species with significant morphological variation? Zool. Anz. 252, 48-75. https://doi.org/10.1016/j.jcz.2012.03.002.

Neves, R.C., Kristensen, R.M., Rohal, M., Thistle, D., Sørensen, M.V., 2019. First report of Loricifera from the North east Pacific region, with the description of two new species. Mar. Biodivers. 49, 1151-1168. https://doi.org/10.1007/s12526-018-0898-1.

Reinhard, W., 1881. Über Echinoderes and Desmoscolex der Umgegend von Odessa. Zool. Anz. 4, 588-592.

Rohal, M., Thistle, D., Easton, E.E., 2014. Meiofaunal abundances and faunal similarity on the continental rise off the coast of California. Deep-Sea Res. I 93, 131-144. https://doi.org/10.1016/j.dsr.2014.07.004.

Sánchez, N., Sørensen, M.V., Landers, S.C., 2019a. Pycnophyidae (Kinorhyncha: Allomalorhagida) from the Gulf of Mexico: Fujuriphyes viserioni sp. nov. and a redescription of Leiocanthus langi (Higgins 1964), with notes on its intraspecific variation. Mar. Biodivers. (in press) https://doi.org/10.1007/s12526-019-00947-x.

Sánchez, N., Pardos, F., Martínez-Arbizu, P., 2019b. Deep-sea Kinorhyncha diversity of the polymetallic nodule fields at the Clarion-Clipperton fracture zone (CCZ). Zool. Anz. 282, 189-205. https://doi.org/10.1016/j.jcz.2019.05.007.

Sørensen, M.V., 2007. A new species of Antygomonas (Kinorhyncha: Cyclorhagida) from the Atlantic coast of Florida, USA. Cah. Biol. Mar. 48, 155-168.

Sørensen, M.V., Dal Zotto, M., Rho, H.S., Herranz, M., Sánchez, N., Pardos, F., Yamasaki, H., 2015. Phylogeny of Kinorhyncha based on morphology and two molecular loci. PLoS One 10 (7), e0133440.

Sørensen, M.V., Herranz, M., Landers, S.C., 2016. A new species of Echinoderes (Kinorhyncha: Cyclorhagida) from the Gulf of Mexico, with a redescription Echinoderes bookhouti Higgins, 1964. Zool. Anz. 265, 48-68. https://doi.org/10. 1016/j.jcz.2016.04.004.

Sørensen, M.V., Landers, S.C., 2014. Two new species of Echinoderes (Kinorhyncha: Cyclorhagida) from the Gulf of Mexico. Front. Mar. Sci. 1 article 8,1-18. https:// doi.org/10.3389/fmars.2014.00008.

Sørensen, M.V., Landers, S.C., 2017. Description of a new species, Paracentrophyes sanchezae n. sp. (Kinorhyncha: Allomalorhagida) from the Gulf of Mexico, with differential notes on one additional, yet undescribed species of the genus. Zootaxa 4242, 61-76. https://doi.org/10.11646/zootaxa.4242.1.3.

Sørensen, M.V., Landers, S.C., 2018. New species of Semnoderidae (Kinorhyncha: Cyclorhagida: Kentrorhagata) from the Gulf of Mexico. Mar. Biodivers. 48, 327-355. https://doi.org/10.1007/s12526-017-0728-x.

Sørensen, M.V., Rho, H.S., Kim, D., 2010. A new species of Condyloderes (Cyclorhagida, Kinorhyncha) from Korea. Zool. Sci. 27, 234-242.

Sørensen, M.V., Rohal, M., Thistle, D., 2018. Deep-sea Echinoderidae (Kinorhyncha: Cyclorhagida) from the Northwest Pacific. Eur. J. Taxon. 456, 1-75. https://doi. org/10.5852/ejt.2018.456.

Yamasaki, H., Neuhaus, B., George, K.H., 2018a. New species of Echinoderes (Kinorhyncha: Cyclorhagida) from Mediterranean seamounts and from the deep-sea floor in the northeast Atlantic ocean, including notes on two undescribed species. Zootaxa 4378, 541-566. https://doi.org/10.11646/zootaxa.4387.3.8.

Yamasaki, H., Neuhaus, B., George, K.H., 2018b. Echinoderidae (Cyclorhagida: Kinorhyncha) from two seamounts and the adjacent deep-sea floor in the Northeast Atlantic Ocean, including descriptions of three new species. Cah. Biol. Mar. 59, 79-106.

Zelinka, C., 1896. Demonstration von Tafeln der Echinoderes-Monographie. Verhandlungen Dtsch. Zool. Ges. 6, 197-199.

Zelinka, K., 1928. Monographie der Echinodera. Verlag Wilhelm Engelmann, Leipzig. 